\title{
Sağlık Göstergeleri Açısından OECD Ülkelerinin EDAS ve ARAS Yöntemleri ile Değerlendirilmesi ${ }^{1}$
} (Araştırma Makalesi)

Evaluation of OECD Countries in terms of Health Indicators with EDAS and ARAS Methods

Doi: 10.29023/alanyaakademik. 664883

\section{Zeynep Özgül SAYGIN}

Yüksek Lisans Mezunu, Pamukkale Üniversitesi, Sosyal Bilimler Enstitüsü, zosaygin@gmail.com

Orcid No: 0000-0003-3831-6142

\section{Nilsen KUNDAKCI}

Doç. Dr., Pamukkale Üniversitesi, İ̈BF, İşletme Bölümü

nilsenk@pau.edu.tr

Orcid No: 0000-0002-7283-320X

Bu makaleye atıfta bulunmak için: Saygın, Z.Ö., \& Kundakcı, N. (2020). Sağlık Göstergeleri Açısından OECD Ülkelerinin EDAS ve ARAS Yöntemleri ile Değerlendirilmesi. Alanya Akademik Baklş, 4(3),

Sayfa No. 911-938.

\begin{abstract}
ÖZET
Anahtar kelimeler:

SWARA, EDAS,

ARAS, Săgllk

Göstergeleri, OECD

Ülkeleri

Makale Geliş Tarihi:

25.12.2019

Kabul Tarihi:

15.09.2020

Ülkelerin sağlıklı bireylerden oluşmasl, gelişmişlik düzeylerini ileriye taşımaları açısından önem taşımaktadır. Bu yüzden sağlık göstergelerini iyileştirmek için yapılacak çalışmalar ülkeleri ve bu ülkelerin vatandaşlarını olumlu yönde etkileyecektir. Bu çalışmada, sağlık gösterge kriterleri açısından OECD'ye üye 36 ülkenin sıralamalarını elde etmek amaçlanmıştır. Elde edilen sıralama sonuçlarına göre ülkelerin konumlarını görerek sağlık alanındaki politikalarını gözden geçirip gerekli önlemleri zamanında almaları sağlanabilecektir. Ülkeler arasında sağlık göstergeleri açısından siralamalarin elde edilmesinde EDAS (Evaluation based on Distance from Average Solution) ve ARAS (Additive Ratio Assessment) yöntemleri kullanılmıştır. Değerlendirme kriteri olarak dikkate alınan sağlık göstergelerinin ăğrlıklarının belirlenmesinde SWARA (Step-wise Weight Assessment Ratio Analysis) yönteminden yararlanılmıştır. Ayrıca, Spearman korelasyon katsayısı kullanılarak EDAS ve ARAS yöntemleri ile elde edilen sıralamalar arasındaki ilişki incelenmiştir.
\end{abstract}

Keywords:

SWARA, EDAS,

ARAS, Health

Indicators, OECD

Countries

\begin{abstract}
The fact that countries are composed of healthy individuals is important in terms of their development levels. Therefore, efforts to improve health indicators will positively affect countries and their citizens. In this study, it is aimed to obtain the rankings of 36 OECD member countries in terms of health indicator criteria. According to the ranking results, countries will be able to see their position and review their health policies and take the necessary precautions in a timely manner. EDAS (Evaluation Based on Distance from Average Solution) and ARAS (Additive Ratio Assessment)
\end{abstract}

${ }^{1}$ Bu çalışma; Zeynep Özgül Saygın'nın 2019 yılında, Pamukkale Üniversitesi- Sosyal Bilimler Enstitüsünde, Nilsen KUNDAKCI’nın danışmanlığında hazırladığı "OECD Ülkelerinin Sağlık Göstergeleri Açısından Bütünleşik Çok Kriterli Karar Verme Yaklaşımı ile Analizi” başlıklı yüksek lisans tezinden üretilmiştir. 
methods were used to obtain the rankings in terms of health indicators among countries. SWARA (Step-wise Weight Assessment Ratio Analysis) method was used to determine the weights of health indicators considered as evaluation criteria. In addition, the relationship between the rankings obtained by EDAS and ARAS methods was investigated by using Spearman correlation coefficient.

\section{GIRIŞ}

Sağlık kavramı fiziksel, ruhsal, zihinsel ve sosyal dört bileşenin kusursuz olmasa bile eksiksiz olması şeklinde tanımlanmaktadır. Bileşenlerden bir tanesinin eksik olduğu durumda "sağlıklı" diye bir tanımın yapılamayacağı belirtilmiştir. Bireylerin hayatlarını mutlu olarak devam ettirmesindeki en önemli unsur sağlıklı olma durumudur. Toplumların sağlıklı bireylerden oluşması ülkelerin gelişmişlik düzeyini ileriye taşıması açısından son derece önemlidir.

Sağlık sektörünün yapısını etkileyen birçok etken bulunmaktadır. Bunların başında ülkenin ekonomisi, izlemiş olduğu politika, nüfus yapısı, kültürel etkileşimler, teknolojik gelişmeler, doğal kaynaklar gelmektedir. Ülkeler arasında değişiklik gösteren bu unsurlar ile birlikte ülkelerin sağlık sektör yapısı da farklılık göstermektedir. Teknolojide meydana gelen hızlı gelişmeler sonucunda sağlık sektöründe önemli gelişmeler ve rekabetin yaşanması kaçınılmaz olmuştur.

Sağlık göstergeleri ülkelerin kalkınma düzeyi hakkında bilgi vermektedir. $\mathrm{Bu}$ nedenle, göstergelerin eksikliği negatif şekilde kalkınmayı etkileyecektir. Ülkelerin gelişmişlik düzeyini belirlemek, kıyaslama yapabilmek için bazı kriterlere gereksinim duyulmaktadır ve bu kriterler tüm dünya tarafindan sağlık göstergeleri olarak tanımlanmaktadır. Sağlık göstergelerinin tüm ülkeler için önemli olmasının başlıca nedenleri arasında; tespit edilen sağlık problemleri, daha iyi sağlık hizmeti almaya yarayan sağlık hizmet planlaması ve ülkelerin sağlık açısından performanslarının karşılaştırılabilmesi gelmektedir. Sağlık göstergeleri ülkenin mevcut durumunu göstermenin yanı sira bu alanda belirli zaman dilimlerinde meydana gelen değişimlerin ve performans değerlerinin belirlenmesine yardımcı olmaktadır. Bunlara ek olarak sağlık sektöründe devletin hangi alanlarda kaliteli ve etkin şekilde ilerlemesi ve gelişim göstermesine yönelik izleyeceği politikaların tespitinde kullanılmaktadır. Ülkeler arasında ekonomik, kültürel ve sosyal farklılıklar bulunduğu için bu sağlık göstergeleri de ülkeden ülkeye değişiklik gösterebilmektedir.

$\mathrm{Bu}$ çalışmada kullanılan sağlık göstergeleri belirlenirken literatürdeki çalışmalar ve uzman görüşleri göz önünde bulundurulmuştur. Tablo 1'de, literatürde yer alan çalışmalarda kullanılan sağlık göstergeleri özetlenmiştir. 
ALANYA AKADEMİK BAKIŞ DERGİSİ 4/3 (2020)

Tablo 1. Literatürde Kullanılan Sağlık Göstergeleri

\begin{tabular}{|c|c|c|c|}
\hline $\begin{array}{c}\text { Yazar ve Yayın } \\
\text { Yılı }\end{array}$ & $\begin{array}{l}\text { Kullanılan } \\
\text { Yöntem }\end{array}$ & $\begin{array}{l}\text { Çalışmanın } \\
\text { Kapsamı }\end{array}$ & Kullanılan Sağlık Göstergeleri \\
\hline $\begin{array}{l}\text { Mirmirani ve } \\
\text { Lippmann (2003) }\end{array}$ & $\begin{array}{l}\text { VZA Yöntemi, } \\
\text { CCR Yaklaşımı, } \\
\text { BBC Yaklaşımı }\end{array}$ & G12 Ülkeleri & $\begin{array}{l}\text { Girdiler: Kişi başına düşen sağlık } \\
\text { harcaması, bin kişi başına düşen hekim, } \\
\text { hastane yatağı ve MRI sayırır, ortalama } \\
\text { okul yaşam süresi } \\
\text { Çıktılar: Doğumda beklenen yaşam süresi, } \\
\text { yeni doğan ölüm oranı }\end{array}$ \\
\hline $\begin{array}{l}\text { Retzlaff-Roberts, } \\
\text { Chang ve Rubin } \\
\text { (2004) }\end{array}$ & VZA Yöntemi & $\begin{array}{l}\text { OECD } \\
\text { ülkeleri }\end{array}$ & $\begin{array}{l}\text { Bin kişiye düşen hekim ve hasta yatağı } \\
\text { sayısı, bir milyon kişiye düşen MRI sayısı, } \\
\text { GSYİH'den sağlı harcamalarına ayrılan } \\
\text { pay, bebek ölüm hızı, doğumda beklenen } \\
\text { yaşam süresi, okul beklentisi, Gini } \\
\text { katsayısı ve sigara kullanım oranı }\end{array}$ \\
\hline $\begin{array}{l}\text { Afonso ve } \\
\text { Aubyn, (2005) }\end{array}$ & $\begin{array}{l}\text { Free Disposable } \\
\text { Hull (FDH), } \\
\text { VZA Yöntemi }\end{array}$ & $\begin{array}{l}\text { OECD } \\
\text { Ülkeleri }\end{array}$ & $\begin{array}{l}\text { Girdiler: Bin kişi başına düşen hastane } \\
\text { yatağı, hekim ve hemşire sayıları } \\
\text { Çıktılar: Bebek yaşam oranı, doğumda } \\
\text { beklenen yaşam süresi, anne ölüm oranı }\end{array}$ \\
\hline Tandon (2005) & VZA Yöntemi & $\begin{array}{l}\text { Birleşmiş } \\
\text { Milletler } \\
\text { Milenyum } \\
\text { Deklarasyonu } \\
\text { kapsamında } \\
189 \text { ülke } \\
\end{array}$ & $\begin{array}{l}\text { Girdiler: Kişi başına düşen sağlı } \\
\text { harcamaları, bin kişi başına düşen hastane } \\
\text { yatağı ve tıbbi personel sayıları } \\
\text { Çıktılar: Beş yaş altı ölüm oranı }\end{array}$ \\
\hline $\begin{array}{l}\text { Spinks ve } \\
\text { Hollingsworth } \\
(2005)\end{array}$ & VZA Yöntemi & $\begin{array}{l}\text { OECD } \\
\text { Ülkeleri }\end{array}$ & $\begin{array}{l}\text { Girdiler: Eğitim, gelir, kişi başına düşen } \\
\text { sağlık harcamaları } \\
\text { Çıktılar: Doğumda beklenen yaşam süresi }\end{array}$ \\
\hline $\begin{array}{l}\text { Afonso ve } \\
\text { Aubyn (2006) }\end{array}$ & VZA Yöntemi & $\begin{array}{l}\text { OECD } \\
\text { Ülkeleri }\end{array}$ & $\begin{array}{l}\text { Girdiler: Bin kişi başına düşen pratisyen } \\
\text { hekim, hemşire, tıbbi tedavide kullanılan } \\
\text { yüksek teknolojili araç ve akut tedavi } \\
\text { yatağı sayıları } \\
\text { Çıktılar: Bebek yaşam oranı, doğumda } \\
\text { beklenen yaşam süresi, ortalama yaşam } \\
\text { süresi }\end{array}$ \\
\hline
\end{tabular}




\begin{tabular}{|c|c|c|c|}
\hline Chu Ng (2008) & $\begin{array}{l}\text { Malmquist toplam } \\
\text { faktör verimlilik } \\
\text { endeksi (TFV) }\end{array}$ & Çin Bölgeleri & $\begin{array}{l}\text { Girdiler: Bin kişi başına düşen hekim, } \\
\text { hemşire, hastane yatağı ve sağlık personeli } \\
\text { sayıları } \\
\text { Çıktılar: Ayakta ve yatarak tedavi sayıları, } \\
\text { ölüm oranı }\end{array}$ \\
\hline Özdemir (2009) & $\begin{array}{l}\text { VZA Yöntemi, } \\
\text { CCR Yaklaşımı }\end{array}$ & $\begin{array}{l}\text { Karadeniz } \\
\text { Ekonomik } \\
\text { İşbirliği } \\
\text { Teşkilatı }\end{array}$ & $\begin{array}{l}\text { Girdiler: Kişi başına yapılan sağlık } \\
\text { harcaması, bin kişi başına düşen doktor } \\
\text { sayısı, bin kişi başına düşen hastane yatak } \\
\text { sayısı } \\
\text { Çıktılar: Nüfus ve sağlıklı beklenen yaş }\end{array}$ \\
\hline Ersöz, (2009) & $\begin{array}{l}\text { Hiyerarşik } \\
\text { kümeleme yöntemi, } \\
\text { K-Ortalamalar } \\
\text { kümeleme, Medoid } \\
\text { kümeleme yöntemi }\end{array}$ & $\begin{array}{l}\text { OECD } \\
\text { ülkeleri }\end{array}$ & $\begin{array}{l}\text { Toplam sağlık harcamalarının GSYH } \\
\text { içindeki oranı, kişi başına düşen sağlık } \\
\text { harcaması, doğumda beklenen yaşam } \\
\text { süresi ve bebek ölüm hızı }\end{array}$ \\
\hline $\begin{array}{l}\text { Kocaman, Mutlu, } \\
\text { Bayraktar ve } \\
\text { Araz (2012) }\end{array}$ & $\begin{array}{l}\text { VZA Yöntemi, } \\
\text { CCR Yaklaşımı }\end{array}$ & $\begin{array}{l}\text { OECD } \\
\text { Ülkeleri }\end{array}$ & $\begin{array}{l}\text { Girdiler: Bin kişi başına düşen hekim } \\
\text { sayısı, bin kişi başına düşen hastane yatağı } \\
\text { sayısı, kişi başına düşen sağlık harcaması, } \\
\text { GSYİH'den sağlık harcamalarına ayrılan } \\
\text { pay } \\
\text { Çıktılar: Doğumda beklenen yaşam süresi, } \\
\text { beş yaş altı ölüm oranı }\end{array}$ \\
\hline Girginer (2013) & $\begin{array}{l}\text { Çok boyutlu } \\
\text { ölçekleme analizi, } \\
\text { Hiyerarşik olmayan } \\
\text { kümeleme analizi }\end{array}$ & $\begin{array}{l}\text { Türkiye ve } \\
\text { AB ülkeleri }\end{array}$ & $\begin{array}{l}\text { Doğumda Yaşam Beklentisi, bin canlı } \\
\text { doğumda } 5 \text { yaşın altındaki çocuklarda } \\
\text { ölüm oranı, bin nüfus başına } 15-59 \text { yaş } \\
\text { arası çocuklarda ölüm oranı, doğumda } \\
\text { sağlıklı yaşam beklentisi, GSYİH'nın } \\
\text { sağlık harcaması payı, toplam sağlık } \\
\text { harcamalarının kişi başına yıllık payı, } \\
\text { toplam sağlık harcamalarından kamu } \\
\text { sağlık harcamaları }\end{array}$ \\
\hline Tekin (2015) & $\begin{array}{l}\text { Kolmogorov- } \\
\text { Smirmov Testi, } \\
\text { Hiyerarşik } \\
\text { kümeleme analizi } \\
\text { yöntemlerinden } \\
\text { Ward's (varyans) } \\
\text { yöntemi }\end{array}$ & $\begin{array}{l}\text { Türkiye'de } \\
\text { yer alan iller }\end{array}$ & 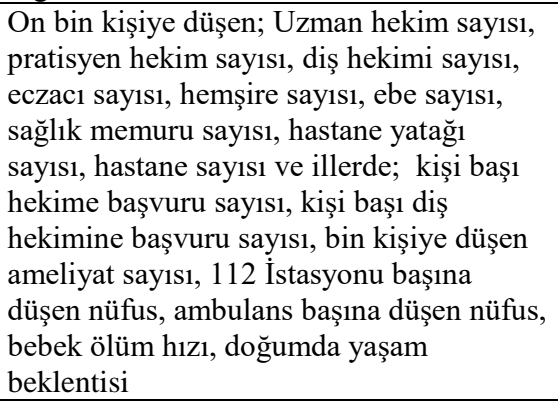 \\
\hline
\end{tabular}




\begin{tabular}{|c|c|c|c|}
\hline $\begin{array}{l}\text { Alptekin ve } \\
\text { Yeşilaydın } \\
\text { (2015) }\end{array}$ & $\begin{array}{l}\text { Bulanık c- } \\
\text { ortalamalar } \\
\text { kümeleme analizi }\end{array}$ & $\begin{array}{l}\text { OECD } \\
\text { ülkeleri }\end{array}$ & $\begin{array}{l}\text { Bin kişiye düşen hekim sayısı ve hasta } \\
\text { yatağ1 sayısı, kişi başı sağlı harcaması, } \\
\text { günlük sigara içen } 15 \text { yaş üstü erişkinlerin } \\
\text { yüzdesi, kişi baş1 meyve tüketimi, kızamık } \\
\text { aş1sı olan } \\
\text { çocukların yüzdesi, karbonmonoksit (CO) } \\
\text { emisyonu, 5-39 yaş arası beklenen } \\
\text { okullaşma oranı, doğumda beklenen yaşam } \\
\text { süresi ve anne ölüm hızı }\end{array}$ \\
\hline $\begin{array}{l}\text { Mut ve Akyürek } \\
\text { (2017) }\end{array}$ & $\begin{array}{l}\text { Hiyerarşik } \\
\text { kümeleme yöntemi, } \\
\text { K-ortalama } \\
\text { kümeleme yöntemi }\end{array}$ & $\begin{array}{l}\text { OECD } \\
\text { ülkeleri }\end{array}$ & $\begin{array}{l}\text { Hekim sayıs1, hasta yatağı sayısı, } \\
\text { GSYIH'den sağlığa ayrılan pay, kızamık } \\
\text { aş1sı olan çocukların yüzdesi, gini } \\
\text { katsayısı, günlük sigara içen } 15 \text { yaşüstü } \\
\text { erişkinlerin yüzdesi, 25-64 yaşüstü } \\
\text { erişkinlerde okullaşma oranı, doğumdan } \\
\text { beklenen yaşam yılı ve bebek ölüm hızı }\end{array}$ \\
\hline $\begin{array}{l}\text { Şener ve Yiğit } \\
(2017)\end{array}$ & $\begin{array}{l}\text { VZA Yöntemi, } \\
\text { CCR ve BCC } \\
\text { modeli }\end{array}$ & $\begin{array}{l}\text { OECD } \\
\text { ülkeleri }\end{array}$ & $\begin{array}{l}\text { Girdiler: Kişi başına düşen hastane yatağı } \\
\text { sayısı, kişi başına düşen hekim sayısı, kişi } \\
\text { başına düşen sağlı harcaması, kişi başına } \\
\text { düşen MRI sayısı ve sigara kullanım oranı } \\
\text { Çıktılar: Bebek ölüm oranı sağlıklı yaşam } \\
\text { beklentisi }\end{array}$ \\
\hline $\begin{array}{l}\text { Sayıl1, Sayman, } \\
\text { Vehid, Köksal ve } \\
\text { Erginöz (2017) }\end{array}$ & $\begin{array}{l}\text { Normal dağılım } \\
\text { sinanması için } \\
\text { değişim katsayısı ve } \\
\text { Shapiro-Wilk Testi, } \\
\text { Tek Örneklem T } \\
\text { testi }\end{array}$ & $\begin{array}{l}\text { OECD } \\
\text { Ülkeleri }\end{array}$ & $\begin{array}{l}\text { Kişi baş1 sağlık harcaması, sağlı } \\
\text { harcamalarının bütçedeki payı, } \\
\text { kadınlardaki yaşam yılı beklentisi, } \\
\text { erkeklerdeki yaşam yılı beklentisi, total } \\
\text { yaşam yılı beklentisi, sağlıklı yaşam yılı } \\
\text { beklentisi, } 15 \text { yaş üzeri kişi baş1 alkol alımı } \\
\text { (litre), neonatal mortalite hızı (bin canlı } \\
\text { doğumda), } 5 \text { yaş altı ölüm hızı (bin canlı } \\
\text { doğumda), anne ölüm hızı (yüz bin canlı } \\
\text { doğumda), } 15 \text { yaş üzeri sigara kullanma } \\
\text { oranı için } 2015 \text { yılı verileri; on bin kişiye } \\
\text { düşen hekim sayısı, on bin kişiye düşen } \\
\text { hemşire ve ebe sayısı, bin kişiye düşen } \\
\text { hastane yatak sayısı, }\end{array}$ \\
\hline Göztepe (2017) & $\begin{array}{l}\text { VIKOR, } \\
\text { TOPSIS }\end{array}$ & $\begin{array}{l}\text { OECD } \\
\text { Ülkeleri }\end{array}$ & $\begin{array}{l}\text { Özel sektör, kamu ve kişi başına düşen } \\
\text { sağlık harcamaları, doğum ve ölüm } \\
\text { oranları, doktor, hemşire/ebe, yatak ve } \\
\text { geliştirilmiş sanitasyon tesis sayıları }\end{array}$ \\
\hline
\end{tabular}

$\mathrm{Bu}$ çalışmada literatürde sağlık alanında yapılan diğer çalışmalardan farklı olarak, Çok Kriterli Karar Verme (ÇKKV) yöntemlerinden SWARA- EDAS ve SWARA-ARAS yöntemlerinin bir arada kullanılmasına dayanan bütünleşik yaklaşımlar yardımıyla OECD'ye üye ülkelerin sağlık göstergeleri açısından sıralamaları belirlenmiştir. Kriter ağırlıklarının belirlenmesinde SWARA yöntemi kullanılmıştır. Literatürde kriter ağırlıklarının belirlenmesinde AHP, MACBETH, Entropi gibi farklı yöntemler de kullanılmaktadır. Bu 
çalışmada SWARA yönteminin seçilmesinin nedeni AHP ve MACBETH yöntemlerine göre daha basit işlemler içermesi ve daha kısa sürede sonuca ulaşılabilmesidir. Ayrıca SWARA yöntemi, diğer yöntemlere göre daha yeni bir yöntemdir. Entropi yöntemi ile kriter ağırlıkları belirlenirken karar vericilerin görüşleri yerine karar matrisindeki verilerden yararlanılır. $\mathrm{Bu}$ çalışmada ise kriter ağırlıkları uzman görüşlerine dayanarak belirlenmiştir. SWARA yönteminde uzmanların kriterler için belirlemiş oldukları sıralamalar, birbirlerinden bağımsız şekilde gerçekleştiği için çok farklı olabilmektedir. Bu nedenle, kriter ağırlıklarının uzmanların görüşleri düzeyinde birbirinden farklılık göstermesi beklenmektedir. $\mathrm{Bu}$ çalışmada, birden fazla uzman görüşünün dikkate alınması nedeniyle, grup kararlarının alınmasında kolaylık sağlayan SWARA yöntemi tercih edilmiştir. Alternatiflerin sıralanmasında ise EDAS ve ARAS yöntemlerinden yararlanılmıştır. Literatürde bu yöntemler dişında birçok ÇKKV yöntemleri mevcuttur. Bu çalışmada EDAS ve ARAS yöntemlerinin tercih edilmesinin nedenleri arasında iki yöntemin nispeten yeni yöntemler olması, karmaşı olmayan hesaplama adımları içermesi ve kolayca sonuca ulaşılması sayılabilir. EDAS ve ARAS yöntemlerinde, ELECTRE ve PROMETHEE yöntemlerinde olduğu gibi alternatifler ikili olarak karşılaştırılmadığından zaman tasarrufu sağlamakta, alternatif sayısının fazla olduğu durumlarda da kolaylıkla kullanılabilmektedirler. Ayrıca, EDAS yöntemi ortalama çözümden pozitif ve negatif mesafeleri dikkate almaktadır. Uzaklığa dayalı diğer bir yöntem olan TOPSIS yöntemine göre daha yeni bir yöntemdir ve TOPSIS yöntemindeki gibi pozitif ve negatif ideal çözümden uzaklıklar hesaplanmaz. ÇKKV yöntemlerinden COPRAS, MOORA, VIKOR yöntemleri de uzaklığa bağlı çözüm sunması bakımından EDAS yöntemi ile benzerdir. Fakat EDAS yönteminde en iyi ve en kötü değerlerin hesaplanması gerekmez. EDAS yönteminde ortalamaya olan pozitif uzaklık ile ortalamaya olan negatif uzaklık dikkate alınır ve ortalamaya oranla daha yüksek pozitif uzaklık değerleri ve ortalamaya oranla daha düşük negatif uzaklık değerleri, çözümün (alternatifin) ortalama çözümden daha iyi olduğunu gösterir (Keshavarz Ghorabaee vd., 2015: 439). ARAS yönteminde ise alternatiflere ait fayda fonksiyon puanlarının oranları ile optimum alternatifin fayda fonksiyon puanı kıyaslanmaktadır. Böylece, sadece alternatiflerin performansları değerlendirilmez aynı zamanda bütün alternatiflerin ideal olan alternatife oranı da ifade edilir. $\mathrm{Bu}$ da ARAS yönteminin diğer yöntemlere göre avantajıdır. Karar problemlerinde, karar vericilerin alternatifleri kıyaslarken taraflı olma endişesi bulunmaktadır. $\mathrm{Bu}$ durum nedeniyle ÇKKV yöntemlerinde mutlak çözümden daha fazla optimum çözüme daha yakın bulunan çözüm aralığı dikkate alınır. ARAS yönteminde ise daha farklı bir durum bulunmaktadır. ARAS yöntemin uygulanışı dikkate alındığında, karar vericilere ait endişenin giderilmesi söz konusudur. ARAS yönteminin karmaşık matematiksel işlemler içermemesi bu yüzden kısa süre zarfında hesaplanıyor oluşu ve kolay anlaşılmasının yanı sıra güvenilir bir yöntem olması çalışmada kullanılmasının diğer avantajları arasındadır.

Alternatifler arasındaki sıralamalar EDAS ve ARAS yöntemleri ile elde edildikten sonra, Spearman korelasyon katsayısı ile elde edilen bu sıralamalar arasındaki ilişki hesaplanmıştır. $\mathrm{Bu}$ çalışma, sağlık göstergeleri açısından ülkelerin diğer ülkeler arasındaki konumlarının tespit edilmesi, sağlı politikalarını gözden geçirmeleri ve gerekli olabilecek iyileştirmeleri tespit edebilmeleri açısından önem arz etmektedir.

$\mathrm{Bu}$ çalışma, altı bölümden oluşmaktadır. Birinci bölümde, konuya ilişkin girişe yer verilmiştir. İkinci bölümde, sağlık göstergelerinin önem düzeylerini belirlemede kullanılan SWARA yöntemi açıklanmıştır. Üçüncü bölümde, OECD ülkelerinin sağlık göstergeleri altında sıralamalarının belirlenmesinde kullanılan ilk yöntem olan EDAS yöntemine 916 
değinilmiştir. Ayrıca, yöntemin adımlarına ve literatür taramasına yer verilmiştir. Dördüncü bölümde, çalışmada ülkelerin sıralanmasında kullanılan diğer yöntem olan ARAS yöntemi açıklanarak yöntemin adımları ve literatürde ARAS yöntemini kullanan çalışmalar özetlenmiştir. Beşinci bölüm olan uygulamada ise OECD’ye üye 36 ülkenin sağlık göstergeleri açısından sıralamalarına ulaşılmıştır. Altıncı bölüm yani sonuç kısmında ise uygulama sonucu elde edilen ülkelerin sıralamaları yorumlanmış ve üye ülkelere sağlık alanında iyileştirme sağlayabilmeleri için önerilerde bulunulmuştur.

\section{SWARA YÖNTEMI}

Keršulienè, Turskis ve Zavadskas (2010) tarafından geliştirilen SWARA (Step-wise Weight Assessment Ratio Analysis) yönteminin Türkçe karşılığı "Adım Adım Ağırlık Değerlendirme Oran Analizi'dir. SWARA yöntemi, uzmanların bilgi ve birikimlerinden faydalanılarak kriterlerin ve alternatiflerin değerlendirilmesine olanak sağlar ve belirsizliklerin üstesinden gelmek için basit göreli karşılaştırmalara dayanır (Keršulienė vd., 2010:410; Ghorshi Nezhad, 2015: 1124).

Literatürde kriterlerin ağırlıklarını belirlerken SWARA yönteminden yararlanan çalışmalar yer almaktadır. Zolfani vd. (2013a), Yang Denge Teorisi ve SWARA yönteminden yararlanarak, yerel ve uluslararası ürünlerin tasarımını yapmışlardır. Zolfani ve Zavadskas (2013), kırsal alanların sürdürülebilir gelişmesini değerlendirmede SWARA ve COPRAS yöntemlerini bir arada kullanmışlardır. Zolfani vd. (2013b), SWARA ve VIKOR yöntemleri ile tünellerdeki mekanik havalandırma alternatiflerini değerlendirmişlerdir. Zolfani ve Bahrami (2014), yatırım önceliği için dört yüksek teknoloji endüstrisi arasından en uygun olanın seçiminde SWARA ve COPRAS yöntemlerini kullanmışlardır. Stanujkic vd. (2015), ideal paket tasarımının belirlenmesinde SWARA yönteminden yararlanmışlardır. Tuş Işık ve Aytaç Adalı (2016), otel seçimi için SWARA ve OCRA yöntemlerini bir arada kullanmışlardır. Çakır (2017), SWARA ve Gri İlişkisel Analiz yöntemlerinden yararlanarak, kentsel dönüşüm kanununun yürürlüğe girmesi ile birlikte yıkımı gerçekleştirilen riskli binanın yerine yeni bir bina inşası için en iyi müteahhit firmasının seçimini yapmıştır. Çakır ve Karabıyık (2017), SWARA ve COPRAS yöntemlerini bir arada kullanılarak bulut depolama alternatiflerini değerlendirmişlerdir. Çakır ve Akar (2017), bir işletme için CNC makinesinin seçiminde, SWARA ve TOPSIS yöntemlerini kullanmışlardır. Vesković vd. (2018), Bosna-Hersek bölgesinde demiryolu şirketleri için dört farklı yönetim modelini SWARA ve MABAC yöntemleri ile değerlendirmişlerdir. Ayyıldız ve Demirci (2018), Türkiye'de 81 ilin performans değerlendirmesinde SWARA ve TOPSIS yöntemlerini bir arada kullanmışlardır. Çakır (2018a), SWARA ve EDAS yöntemleri yardımıyla e-devlet uygulamasının bir uzantısı olan, sanal ortamda belgelerin saklanabilmesi ve aynı zamanda kamu kurumlarının denetlenmesinde kullanılan Elektronik Belge Yönetim Sistem (EBYS) yazılımının seçimini yapmıştır.

Kriter ağırlıklarının SWARA yöntemi ile belirlenmesinde izlenen adımlar aşağıdaki gibi özetlenebilir (Özbek, 2017: 46):

Adım 1:Öncelikle, uzmanlar kriterleri en önemli kriter başta, en az öneme sahip kriter sonda olmak üzere azalan önem derecesine göre siralarlar. Eğer birden fazla uzman kriterleri değerlendirecekse, tüm karar vericilerden kriterleri kendileri açısından en önemliden en önemsize doğru sıralamaları istenir (Ruzgys vd., 2014: 107). 
Adım 2:Bu adımda j. kriter $(\mathrm{j}+1)$. ile karşılaştırılır ve $\mathrm{j}$. kriterin $(\mathrm{j}+1)$. kriterden ne düzeyde önemli olduğu belirlenerek bütün kriterler için göreceli önem düzeyleri hesaplanır (Özbek, 2017: 43). $s_{j}$ ile gösterilen bu oran beş ve beşin katları şeklinde belirlenir ve "ortalama değerin karşılaştırmalı önemi" olarak adlandırılır.

Adım 3:Eşitlik (1) kullanılarak, her bir kriter için $k_{j}$ katsayısı hesaplanır.

$$
k_{j}= \begin{cases}1 & j=1 \\ s_{j}+1 & j>1\end{cases}
$$

Adım 4:Eşitlik (2) yardımıyla, önem vektörü $q_{j}$, değişkeni hesaplanır.

$$
q_{j}= \begin{cases}1 & \mathrm{j}=1 \\ \frac{\mathrm{q}_{\mathrm{j}-1}}{\mathrm{k}_{\mathrm{j}}} & \mathrm{j}>1\end{cases}
$$

Adım 5: Eşitlik (3) kullanılarak, kriterlere ait ağırlıklar $w_{j}$ belirlenir.

$$
w_{j}=\left\{\frac{q_{j}}{\sum_{k=1}^{n} q_{k}}\right.
$$

Burada; $w_{j}$, j. kriterin göreli ağırlığını göstermektedir.

\section{EDAS YÖNTEMI}

EDAS (Evaluation based on Distance from Average Solution) yöntemi ilk kez 2015 yılında Keshavarz Ghorabaee vd. tarafından geliştirilmiştir. Alternatiflerin değerlendirilmesi için, EDAS yöntemi ortalama bir çözümden pozitif ve negatif mesafeleri dikkate almaktadır. Ortalama çözümün hesaplanması oldukça basittir ve her bir kriter için farklı alternatiflerin performans değerlerinin aritmetik ortalaması belirlenmelidir (Keshavarz Ghorabaee vd., 2017: 1629).

EDAS yönteminin adımları aşağıdaki gibi özetlenebilir (Keshavarz Ghorabaee vd., 2015: 439):

Adım 1: İlk adımda karar problemine ait kriterler ve alternatifleri gösteren karar matrisi (X) oluşturulur.

$$
X=\left[X_{i j}\right]_{m x n}=\left[\begin{array}{ccc}
X_{11} & \cdots & X_{1 n} \\
\vdots & \ddots & \vdots \\
X_{m 1} & \cdots & X_{m n}
\end{array}\right] \quad(i=1,2, \ldots, m \text { ve } j=1,2, \ldots, n)
$$

Eşitlik (4)'deki $X_{i j}$, i'ninci alternatifin j'ninci kriter için performans değerini belirtmektedir.

Adım 2: Tüm kriterlere göre ortalama çözüm belirlenir ve ortalama değerler matrisi Eşitlik

(5) ve Eşitlik (6) yardımıyla oluşturulur.

$$
A V=\left[A V_{j}\right]_{1 \times n}
$$

Eşitlik (5)'deki AVj, j'ninci kriter altında alternatiflerin aldıkları değerlerin ortalamasını belirtmektedir ve Eşitlik (6)'da görüldüğü gibi hesaplanmaktadır.

$$
A V_{j}=\frac{\sum_{i=1}^{m} X_{i j}}{m}
$$


Adım 3: Her kriter için ortalamadan pozitif uzaklık matrisi (PDA) ve ortalamadan negatif uzaklık matrisi (NDA) oluşturulur. Kriterlerin fayda veya maliyet cinsinden oluşuna göre hesaplamalarında değişiklikler mevcuttur.

$$
\begin{aligned}
& P D A=\left[P D A_{i j}\right]_{m x n} \\
& N D A=\left[N D A_{i j}\right]_{m x n}
\end{aligned}
$$

Kriter fayda kriteri ise;

$$
\begin{aligned}
P D A_{i j} & =\frac{\max \left(0,\left(\mathrm{X}_{\mathrm{ij}-}-\mathrm{AV}_{\mathrm{j}}\right)\right)}{\mathrm{AV}_{\mathrm{j}}} \\
N D A_{i j} & =\frac{\max \left(0,\left(\mathrm{AV}_{\mathrm{j}}-\mathrm{X}_{\mathrm{ij}}\right)\right)}{\mathrm{AV}_{\mathrm{j}}}
\end{aligned}
$$

Kriter maliyet kriteri ise;

$$
\begin{gathered}
P D A_{i j}=\frac{\max ,\left(0,\left(\mathrm{AV}_{\mathrm{j}}-\mathrm{X}_{\mathrm{ij}}\right)\right)}{\mathrm{AV}_{\mathrm{j}}} \\
N D A_{i j}=\frac{\max \left(0,\left(\mathrm{X}_{\mathrm{ij}}-\mathrm{AV}_{\mathrm{j}}\right)\right)}{\mathrm{AV_{ \textrm {j } }}}
\end{gathered}
$$

$P D A_{i j} i$ 'ninci alternatifin j'ninci kriterdeki ortalama çözüme pozitif uzaklığını ve $N D A_{i j}$ ise negatif uzaklığını belirtmektedir.

Adım 4: Tüm alternatifler için PDA ve NDA'nın ağırlıklı toplam değerleri Eşitlik (13) ve Eşitlik (14) yardımıyla hesaplanır.

$$
\begin{aligned}
& S P_{i}=\sum_{j=1}^{n} w_{j} \cdot P D A_{i j} \\
& S N_{i}=\sum_{j=1}^{n} w_{j} \cdot N D A_{i j}
\end{aligned}
$$

Adım 5: Tüm alternatifler için Eşitlik (15) ve Eşitlik (16) kullanılarak $S P_{i}$ ve $S N_{i}$ değerleri normalize edilir.

$$
\begin{gathered}
N S P_{i}=\frac{S P_{i}}{\max _{i}\left(S P_{i}\right)} \\
N S N_{i}=1-\frac{S N_{i}}{\max _{i}\left(S N_{i}\right)}
\end{gathered}
$$

Adım 6: Tüm alternatifler için değerlendirme puanı $A S_{i}$ hesaplanır.

$$
A S_{i}=\frac{1}{2} \cdot\left(N S P_{i}+N S N_{i}\right)
$$

Eşitlik 17 'de ; $0 \leq A S_{i} \leq 1$ 'dir.

Adım 7: Alternatifler değerlendirme puanlarına göre sıralanır ve en yüksek puana sahip olan alternatif en iyisi olarak kabul edilir.

Literatürde EDAS yöntemini farklı alanlara uygulayan çalışmalar yer almaktadır. Keshavarz Ghorabaee vd. (2015), geliştirdikleri EDAS yöntemini, envanter kalemlerinin ABC sınıflandırılmasında uygulamışlardır. Juodagalvienè vd. (2017), bir ailenin yaşayacağı evin temel şeklini seçmek için "güvenlik, enerji tasarrufu, yerleşim düzeni ve malzeme maliyeti" 
kriterleri altında en uygun konut alternatifini SWARA ve EDAS yöntemleri yardımıyla belirlemişlerdir. Ecer (2017), üçüncü parti lojistik sağlayıcı seçiminde bulanık AHP ve EDAS yöntemlerini bir arada kullanmıştır. Ulutaş (2017), işletme için önemli bir maliyet unsuru sayılan yüksek teknolojiye sahip bir dikiş makinesinin seçiminde EDAS yöntemini kullanmıştır. Albayrak ve Erkayman (2018), çalışmalarında teknolojinin hızla gelişmesiyle birlikte popüler bir teknolojik ürün haline gelen akıllı bilekliklerin performans değerlendirmesinde bulanık DEMATEL ve EDAS yöntemlerinden yararlanmışlardır. Özbek ve Engür (2018), yedi adet lojistik firmasının web sitesini on bir kriter altında EDAS yöntemi yardımıyla değerlendirmiştir. Arslan (2018), AHP ve EDAS yöntemlerini kullanarak, en iyi dokuma makinesi seçimini, döşemelik kadife üretim işletmelerine fayda sağlamak amacıyla gerçekleştirmiştir. Chatterjee vd. (2018), EDAS yöntemini kullanarak otomobillerde tampon malzemesi ve dişli seçimine ilişkin değerlendirme yapmışlardır. Çakır (2018b), fitness merkezlerini değerlendirmek için SWARA ve EDAS yöntemlerini bir arada kullanmıştır. Karabašević vd. (2018), yerel bir bilişim teknoloji şirketi için, alanında uzman 2 kişinin belirlenmesinde SWARA ve EDAS yöntemlerinden faydalanmışlardır. Özbek (2019), Türkiye'deki illerin yaşanabilirlik sıralamasına, WASPAS ve EDAS yöntemlerini kullanarak ulaşmıştır.

\section{ARAS YÖNTEMI}

ARAS (Additive Ratio Assessment) yöntemi, ÇKKV problemlerine çözüm aramak amaciyla Zavadskas ve Turskis tarafından 2010 yılında geliştirilmiştir (Zavadskas ve Turskis,2010). Yöntemde, alternatiflere ait fayda fonksiyon puanlarının oranları ile optimum alternatifin fayda fonksiyon puanı kıyaslanmaktadır. Bu nedenle, ARAS yönteminin sadece alternatiflerin performanslarını değerlendirmediği, aynı zamanda bütün alternatiflerin ideal olana oranını gösterdiği ortaya konulmuştur (Shariati vd., 2014: 411).

Aras yöntemi kullanılırken uygulanması gereken adımlar sırasıyla aşağıda belirtilmiştir (Zavadskas ve Turskis, 2010; Ercan ve Kundakc1, 2017).

Adım 1: İlk adımda karar matrisi X oluşturulur.

$$
X=\left[\begin{array}{cccc}
x_{01} & x_{02} & \cdots & x_{0 n} \\
x_{11} & x_{12} & \cdots & x_{1 n} \\
\vdots & \vdots & \ddots & \vdots \\
x_{m 1} & x_{m 2} & \cdots & x_{m n}
\end{array}\right] \quad i=0,1, \ldots, m j=1,2, \ldots, n
$$

Burada $X_{i j}$, i'ninci alternatifin j'ninci kriter altındaki performans değerini göstermektedir ve $X_{o j}$, j'ninci kriterin optimal değerini göstermektedir. $\mathrm{Bu}$ değer, fayda ve maliyet kriteri olmasına göre Eşitlik (19) veya Eşitlik (20) yardımıyla hesaplanmaktadır. Ayrıca bu değer karar vericiler tarafindan da belirlenebilir.

Fayda kriteri için:

$$
\mathrm{X}_{o j}=\max _{i} x_{i j} \quad(i=1,2, \ldots . \mathrm{m} \quad j=1,2, \ldots . \mathrm{n})
$$

Maliyet kriteri için:

$$
\mathrm{X}_{o j}=\min _{i} x_{i j} \quad(i=1,2, \ldots . \mathrm{m} \quad j=1,2, \ldots . \mathrm{n})
$$


Adım 2: Daha sonraki adımda karar matrisi kriterin fayda ve maliyet kriteri olmasına göre Eşitlik (21) veya Eşitlik (22) ile normalize edilmektedir.

Eğer fayda kriteri ise Eşitlik (21) yardımıyla normalizasyon işlemi yapılır;

$$
n_{i j}=\overline{x_{\imath \jmath}}=\frac{x_{i j}}{\sum_{i=0}^{m} x_{i j}} \quad i=0,1, \ldots, m \quad j=1,2, \ldots, n
$$

Eğer maliyet kriteri ise Eşitlik (22) yardımıyla normalizasyon işlemi yapılır;

$$
n_{i j}=\overline{x_{\imath j}}=\frac{1 / x_{i j}}{\sum_{i=0}^{m} 1 / x_{i j}} \quad i=0,1, \ldots, m \quad j=1,2, \ldots, n
$$

Adım 3: Daha sonra ağırlıklandırılmış normalize matris Eşitlik (23) kullanılarak oluşturulur.

$$
r_{i j}=w_{j} . n_{i j} \quad i=0,1, \ldots, m j=1,2, \ldots, n
$$

Burada $w_{j}$, j'ninci kriterin ağırlığını göstermektedir ve Eşitlik (24)'de gösterildiği gibi ağırlıklar toplamı 1'e eşit olmak durumundadır.

$$
\sum_{j=1}^{n} w_{j}=1 \quad j=1,2, \ldots, n
$$

Adım 4: Daha sonra, optimizasyon işlevi Eşitlik (25) ile belirlenir.

$$
S_{i}=\sum_{j=1}^{n} r_{i j} \quad i=0,1, \ldots, m \quad j=1,2, \ldots, n
$$

Buradaki $S_{i}$, $i$ 'ninci alternatifin optimizasyon fonksiyon değerini göstermektedir. Optimum fonksiyon değeri $S_{i}$, ne kadar yüksekse alternatif de o kadar iyidir.

Adım 5: Bu adımda, her bir alternatif için fayda değerini gösteren $K_{i}$ değeri Eşitlik (26) yardımı ile hesaplanmaktadır. Fayda derecesi, alternatifin $S_{i}$ değerleri ile en iyi $S_{0}$ değerlerinin karşılaştırılmasıyla belirlenmektedir.

$$
K_{i}=\frac{s_{i}}{s_{0}} \quad i=0,1, \ldots, m
$$

Buradaki $S_{i}$ ve $S_{0}$ değerleri Eşitlik (25) ile elde edilen optimal kriter değerleridir.

Adım 6: Son adımda $K_{i}$ değerleri büyükten küçüğe doğru sıralanır ve en yüksek değeri alan alternatif en iyisi olarak belirlenir.

Literatürde, ARAS yöntemini ele alan çalışmalar bulunmaktadır. Zavadskas ve Turkis (2010), ofis odalarında mikro iklim değerlendirilmesinin bir örneğini ARAS yöntemini kullanarak sunmuşlardır. Stanujkic ve Jovanovic (2012), fakülteler arasında oluşan rekabet ortamında önemli bir gösterge olarak kabul edilen fakülte web sitelerinin kalite değerlendirmesi için ARAS yöntemini kullanmışlardır. Balezentiene ve Kusta (2012), Litvanya'da otlak ekosistemlerindeki sera gazı emisyonlarının azaltılmasına yönelik yaptıkları çalışmalarında sürdürülebilir gübre yönetiminin çok kriterli değerlendirilmesinde ARAS yöntemini kullanılmışlardır. Sliogeriene vd. (2013), AHP ve ARAS yöntemleri ile Litvanya'nın enerji üretim teknolojilerinin analiz ve seçimini yapmışlardır. Kutut vd. (2013), Litvanya'nın başkenti Vilnius şehrinde, restorasyon veya bakım amacıyla kültürel miras olan tarihi yapıların öncelikli olarak korunmaya alınmasına yönelik sıralamada en uygun alternatifi belirlemek için AHP ile ARAS yöntemlerini kullanmışlardır. Reza ve Majid (2013), ANP ve ARAS yöntemleri ile çevrimiçi bankacılıkta güvene dayalı finansal kurumların performans sıralanmasını yapmışlardır. Darji ve Rao (2014), şeker enstitüsünde yedi kriter altında, altı 
alternatif malzemeyi TODIM, OCRA, ARAS ve EVAMIX yöntemleriyle incelenmişlerdir. Yıldırım (2015), konut satın alma karar problemini ARAS yöntemini kullanarak ele almışlardır. Karabašević vd. (2015), SWARA ve ARAS yöntemlerini telekomünikasyon sektöründe personel seçiminde kullanmışlardır. Paul vd. (2016), Hindistan'ın değişik bölgelerinde görevli polislerin performanslarını değerlendirmede Entropi ve ARAS yöntemlerini kullanmışlardır. Ecer (2016), işletmelerin verimli olarak faaliyetlerini devam ettirmelerine yönelik birden fazla fonksiyonu bir araya toplayan Kurumsal Kaynak Planlaması (ERP) yazılımı seçiminde ARAS yönteminden yararlanmışlardır. Ercan ve Kundakc1 (2017), bir tekstil işletmesinin müşterilerine en uygun numune örneklerini hazırlaması için bir desen programı seçiminde MACBETH, OCRA ve ARAS yöntemlerini bir arada kullanılmışlardır. Arslan (2017), AHP ve ARAS yöntemleri ile Gürcistan merkezli lojistik firmasının toplu araç alımında en iyi alternatifi belirlemiştir. Genç vd. (2017), Karadeniz Ekonomik İşbirliğine üye olan ülkelerin performans değerlendirmesi için TOPSIS, MOORA ve ARAS yöntemlerini kullanmışlardır. Bakır ve Atalık (2018), havayolu taşımacılığında rekabet avantajı sağlamaya yönelik hizmet kalitesinin değerlendirilmesinde alternatif olarak en fazla yolcu taşıyan on bir havayolu işletmesini Entropi ve ARAS yöntemleri ile değerlendirmiştir.

\section{UYGULAMA}

Uygulama bölümünde, OECD’ye üye 36 ülkenin sağlık göstergeleri açısından performansları değerlendirilerek, ülkeler arasındaki sıralamalara ulaşılmıştır. Ayrıca, Türkiye'nin sıralama sonucu diğer üye ülkelerle karşılaştırılmıştır. OECD açılımı ile Ekonomik Kalkınma ve İşbirliği Örgütü, 14 Aralık 1960'da imzalanan Paris Sözleşmesine dayanılarak kurulan uluslararası düzeyde ekonomik bir örgüttür. OECD, ülkelere izlemiş olduğu politikaları karşılaştırabileceği, problemi çözmek için başvurabileceği hem ulusal hem de uluslararası politikaları koordine etmek için çalışma ortamı sunmaktadır (Sayılı, 2017: 2). OECD'nin kökenleri, 18 Avrupa ülkesi ve ek olarak ABD ve Kanada'nın ekonomik bir örgüt olmak için güçlerini birleştirdiği 1960'lara dayanmaktadır. Günümüzde ise 36 üye ülke ile Kuzey ve Güney Amerika'dan, Avrupa ve Asya-Pasifik'e kadar dünyayı kapsamaktadır. Üye ülkelerin çoğunluğu Dünya'nın en gelişmiş ülkeleri olmakla birlikte Meksika, Şili ve Türkiye gibi gelişmekte olan ülkeleri de kapsamaktadır. Mevcut üye ülkeler; Avustralya, Avusturya, Belçika, Kanada, Şili, Çek Cumhuriyeti, Danimarka, Estonya, Finlandiya, Fransa, Almanya, Yunanistan, Macaristan, İzlanda, İrlanda, İsrail, İtalya, Japonya, Kore, Letonya, Litvanya, Lüksemburg, Meksika, Hollanda, Yeni Zelanda, Norveç, Polonya, Portekiz, Slovakya, Slovenya, İspanya, İsveç, İsviçre, Türkiye, Birleşik Krallık, Amerika Birleşik Devletleri'dir. Türkiye, OECD örgütünün kurucu üyelerindendir.

Uygulama aşamasında ilk olarak, literatür taraması ve uzman görüşleri göz önünde bulundurularak çalışmada kullanılacak olan sağlık göstergeleri aşağıda belirtildiği şekilde belirlenmiştir:

Sağlık Harcamaları \% (K1): Sağlık harcamaları, kişisel sağlık bakımı (iyileştirici bakım, rehabilitasyon bakımı, uzun süreli bakım, yardımcı hizmetler ve tıbbi ürünler) ve toplu hizmetler (önleme ve halk sağlığı hizmetleri) dahil olmak üzere, sağlık hizmetlerinin nihai tüketimini ölçmektedir. Bu gösterge yatırımlara yapılan harcamalar hariç tutularak sağlık harcamalarının GSYİH'daki payı olarak ölçülmüştür. 
Hastane Yatak Sayısı (1000 kişi başına) (K2): Bir ülkede hastanede yer alan servis yatakları, rehabilitasyon bakım yatakları, uzun süreli bakım yatakları ve diğer yatakları içermektedir. Her 1000 kişi başına düşen hastane yatak sayısını göstermektedir.

Doktor Sayısı (1000 kişi başına) (K3): Hasta bakımına doğrudan katkıda bulunan doktorlar dikkate alınmıştır ve bin kişi başına düşen doktor sayısını göstermektedir.

Hemşire Sayısı (1000 kişi başına) (K4): Serbest çalışan hemşireler de dâhil olmak üzere hastalara doğrudan sağlık hizmeti sunan tüm hemşireleri içermektedir. Bu gösterge bin kişi başına ölçülmüştür.

Doğumda Beklenen Yaşam Süresi (K5): Doğumda beklenen yaşam süresi, mevcut ölüm oranları değişmezse ortalama olarak bir yeni doğanın ne kadar süre yaşayabileceğini belirtmektedir.

Bebek Ölüm Oranları (K6): Bebek ölümleri, bir yaşın altındaki çocukların ölüm sayısı olarak tanımlanmaktadır ve bebek ölüm oranları 1,000 canlı doğum başına ölçülmektedir.

Tıbbi Teknoloji (K7): Tıbbi teknoloji hastalıkların tanısı ve tedavisinde, sağlık problemlerini çözmek için sağlık personeli tarafindan kullanılan yöntemlerdir. Tıbbi malzeme ve cihazları, cerrahi yöntem ve ilaçları kapsamaktadır. Bu çalışmada, tıbbi cihaz verileri kullanılmıştır.

Tip Mezunları (K8): Tıp mezunları, belirli bir yıldaki tıp fakültelerinden veya benzeri kurumlardan mezun olan öğrenci sayısını göstermektedir. Bu gösterge 100,000 kişi başına ölçülmüştür.

Belirlenen bu sekiz adet sağlık göstergesi kriterinin önem düzeylerini belirlemede SWARA yöntemi kullanılmıştır. Daha sonra ÇKKV yöntemlerinden olan EDAS ve ARAS yöntemleri kullanılarak ülkeler arasındaki sıralamalara ulaşılmıştır. Elde edilen sıralama sonuçları arasındaki ilişkiyi belirlemek için Spearman Korelasyon Katsayısı kullanılmıştır.

\subsection{Kriterlerin Ağırlıklarının SWARA Yöntemi Yardımıyla Belirlenmesi}

İlk olarak, sağlık sektöründe alanında uzman altı karar verici belirlenmiş olan sekiz kriterleri önem derecesine göre sıralamıştır. Elde edilen sıralama sonuçları Tablo 2'de görülmektedir.

Tablo 2. Karar Vericiler için Kriter Sıralamaları

\begin{tabular}{lcccccc}
\hline Kriterler & $\mathbf{K V}_{\mathbf{1}}$ & $\mathbf{K V}_{\mathbf{2}}$ & $\mathbf{K V} \mathbf{3}$ & $\mathbf{K V}_{\mathbf{4}}$ & $\mathbf{K V} \mathbf{5}$ & $\mathbf{K V}_{\mathbf{6}}$ \\
\hline $\mathrm{K}_{1}$ & 2 & 2 & 4 & 2 & 3 & 6 \\
$\mathrm{~K}_{2}$ & 3 & 6 & 7 & 5 & 7 & 5 \\
$\mathrm{~K}_{3}$ & 5 & 1 & 2 & 3 & 4 & 3 \\
$\mathrm{~K}_{4}$ & 4 & 5 & 6 & 4 & 5 & 4 \\
$\mathrm{~K}_{5}$ & 7 & 4 & 5 & 7 & 2 & 2 \\
$\mathrm{~K}_{6}$ & 1 & 3 & 1 & 1 & 1 & 1 \\
$\mathrm{~K}_{7}$ & 6 & 8 & 3 & 6 & 6 & 7 \\
$\mathrm{~K}_{8}$ & 8 & 7 & 8 & 8 & 8 & 8 \\
\hline
\end{tabular}

Daha sonra, her bir karar vericiden oluşturdukları sıralamalar doğrultusunda kriterleri kıyaslayarak göreli önem düzeyi (sj ) değerlerini belirlemeleri istenmiştir. Elde edilen değerler Tablo 3 'te verilmiştir. 
Tablo 3. Kriterlerin Göreceli Önem Düzeyi

\begin{tabular}{|c|c|c|c|c|c|c|c|c|c|c|c|c|}
\hline \multirow{2}{*}{$\begin{array}{l}\text { Önem } \\
\text { Sirası }\end{array}$} & \multicolumn{2}{|c|}{$\mathrm{KV}_{1}$} & \multicolumn{2}{|c|}{$\mathrm{KV}_{2}$} & \multicolumn{2}{|c|}{$\mathrm{KV}_{3}$} & \multicolumn{2}{|c|}{$\mathrm{KV}_{4}$} & \multicolumn{2}{|c|}{$\mathrm{KV}_{5}$} & \multicolumn{2}{|c|}{$\mathrm{KV}_{6}$} \\
\hline & SK & $\overline{\mathbf{S}_{\mathbf{j}}}$ & SK & $\mathbf{S}_{\mathbf{j}}$ & SK & $\mathbf{S}_{\mathbf{j}}$ & SK & $\mathbf{S}_{\mathbf{j}}$ & SK & $\overline{\mathbf{S}_{\mathbf{j}}}$ & SK & $\mathbf{S}_{\mathbf{j}}$ \\
\hline 1 & $\mathrm{~K}_{6}$ & & $\mathrm{~K}_{3}$ & & $\mathrm{~K}_{6}$ & & $\mathrm{~K}_{6}$ & & $\mathrm{~K}_{6}$ & & $\mathrm{~K}_{6}$ & \\
\hline 2 & $\mathrm{~K}_{1}$ & 0.10 & $\mathrm{~K}_{1}$ & 0.05 & $\mathrm{~K}_{3}$ & 0.05 & $\mathrm{~K}_{1}$ & 0.10 & $\mathrm{~K}_{5}$ & 0.05 & $\mathrm{~K}_{5}$ & 0.05 \\
\hline 3 & $\mathrm{~K}_{2}$ & 0.10 & $\mathrm{~K}_{6}$ & 0.05 & $\mathrm{~K}_{7}$ & 0.05 & $\mathrm{~K}_{3}$ & 0.10 & $\mathrm{~K}_{1}$ & 0.05 & $\mathrm{~K}_{3}$ & 0.05 \\
\hline 4 & $\mathrm{~K}_{4}$ & 0.05 & $\mathrm{~K}_{5}$ & 0.10 & $\mathrm{~K}_{1}$ & 0.10 & $\mathrm{~K}_{4}$ & 0.10 & $\mathrm{~K}_{3}$ & 0.05 & $\mathrm{~K}_{4}$ & 0.10 \\
\hline 5 & $\mathrm{~K}_{3}$ & 0.05 & $\mathrm{~K}_{4}$ & 0.05 & $\mathrm{~K}_{5}$ & 0.05 & $\mathrm{~K}_{2}$ & 0.05 & $\mathrm{~K}_{4}$ & 0.10 & $\mathrm{~K}_{2}$ & 0.05 \\
\hline 6 & $\mathrm{~K}_{7}$ & 0.05 & $\mathrm{~K}_{2}$ & 0.05 & $\mathrm{~K}_{4}$ & 0.05 & $\mathrm{~K}_{7}$ & 0.05 & $\mathrm{~K}_{7}$ & 0.05 & $\mathrm{~K}_{1}$ & 0.05 \\
\hline 7 & $\mathrm{~K}_{5}$ & 0.05 & $\mathrm{~K}_{8}$ & 0.05 & $\mathrm{~K}_{2}$ & 0.05 & $\mathrm{~K}_{5}$ & 0.10 & $\mathrm{~K}_{2}$ & 0.05 & $\mathrm{~K}_{7}$ & 0.10 \\
\hline 8 & $\mathrm{~K}_{8}$ & 0.10 & $\mathrm{~K}_{7}$ & 0.05 & $\mathrm{~K}_{8}$ & 0.05 & $\mathrm{~K}_{8}$ & 0.10 & $\mathrm{~K}_{8}$ & 0.15 & $\mathrm{~K}_{8}$ & 0.15 \\
\hline
\end{tabular}

Bir sonraki adımda sj değerlerinden yararlanılarak Eşitlik (1)'de görüldüğü üzere, katsayı (kj) değerleri hesaplanmıştır. Daha sonra, önem vektörü $\left(q_{i}\right)$ değerleri Eşitlik (2) yardımıyla, kriterlerin ağırlıkları $\left(w_{j}\right)$ Eşitlik (3) kullanılarak elde edilmiştir. Birinci karar vericiye ait hesaplamalar sonucu kriterler için elde edilen veriler Tablo 4 'te görülmektedir.

Tablo 4. Birinci Karar Verici için Kriter Ağırlıkları

\begin{tabular}{lccccc}
\hline Kriterler & Önem Sirası & $\boldsymbol{S}_{\boldsymbol{j}}$ & $\boldsymbol{K}_{\boldsymbol{j}}$ & $\boldsymbol{q}_{\boldsymbol{j}}$ & $\boldsymbol{w}_{\boldsymbol{j}}$ \\
\hline $\mathrm{K}_{1}$ & 2 & & 1.000 & 1.000 & 0.159 \\
$\mathrm{~K}_{2}$ & 3 & 0.100 & 1.100 & 0.909 & 0.145 \\
$\mathrm{~K}_{3}$ & 5 & 0.100 & 1.100 & 0.826 & 0.132 \\
$\mathrm{~K}_{4}$ & 4 & 0.050 & 1.050 & 0.787 & 0.125 \\
$\mathrm{~K}_{5}$ & 7 & 0.050 & 1.050 & 0.750 & 0.119 \\
$\mathrm{~K}_{6}$ & 1 & 0.050 & 1.050 & 0.714 & 0.114 \\
$\mathrm{~K}_{7}$ & 6 & 0.050 & 1.050 & 0.680 & 0.108 \\
$\mathrm{~K}_{8}$ & 8 & 0.100 & 1.100 & 0.618 & 0.098 \\
\hline
\end{tabular}

Daha sonra, benzer şekilde sırasıyla tüm karar vericiler için aynı hesaplamalar yapılmış ve Tablo 5'te görüldüğü üzere her karar verici için kriter ağırlıkları elde edilmiştir.

Tablo 5. Karar vericiler için hesaplanan Kriter Ağırlıkları

\begin{tabular}{cccccccc}
\hline Kriterler & $\mathbf{K V}_{\mathbf{1}}$ & $\mathbf{K V}_{\mathbf{2}}$ & $\mathbf{K V}_{\mathbf{3}}$ & $\mathbf{K V}_{\mathbf{4}}$ & $\mathbf{K V}_{\mathbf{5}}$ & $\mathbf{K V}_{\mathbf{6}}$ & $\begin{array}{c}\text { GEO. } \\
\text { ORT }\end{array}$ \\
\hline $\mathrm{K}_{1}$ & 0.145 & 0.144 & 0.13 & 0.150 & 0.138 & 0.115 & 0.135 \\
$\mathrm{~K}_{2}$ & 0.132 & 0.113 & 0.11 & 0.12 & 0.108 & 0.121 & 0.116 \\
$\mathrm{~K}_{3}$ & 0.119 & 0.151 & 0.14 & 0.14 & 0.131 & 0.14 & 0.137 \\
$\mathrm{~K}_{4}$ & 0.125 & 0.119 & 0.11 & 0.12 & 0.119 & 0.127 & 0.121 \\
$\mathrm{~K}_{5}$ & 0.108 & 0.125 & 0.12 & 0.1 & 0.145 & 0.147 & 0.123 \\
$\mathrm{~K}_{6}$ & 0.159 & 0.137 & 0.15 & 0.17 & 0.152 & 0.154 & 0.153 \\
$\mathrm{~K}_{7}$ & 0.114 & 0.103 & 0.14 & 0.11 & 0.114 & 0.105 & 0.114 \\
$\mathrm{~K}_{8}$ & 0.098 & 0.108 & 0.10 & 0.09 & 0.094 & 0.091 & 0.098 \\
\hline
\end{tabular}


Her bir kriter için altı karar verici tarafindan hesaplanarak belirlenen değerlerin bütünleştirilme işlemi geometrik ortalamaları alınarak hesaplanmıştır ve Tablo 6'dagörüldüğü gibi kriterlerin nihai ağırlıkları elde edilmiştir.

Tablo 6. Kriterlerin Nihai Ağırlıkları

\begin{tabular}{cc}
\hline Kriterler & Nihai Kriter Ăgırlıkları \\
\hline $\mathrm{K}_{1}$ & 0.135 \\
$\mathrm{~K}_{2}$ & 0.116 \\
$\mathrm{~K}_{3}$ & 0.137 \\
$\mathrm{~K}_{4}$ & 0.121 \\
$\mathrm{~K}_{5}$ & 0.123 \\
$\mathrm{~K}_{6}$ & 0.153 \\
$\mathrm{~K}_{7}$ & 0.114 \\
$\mathrm{~K}_{8}$ & 0.098 \\
\hline
\end{tabular}

SWARA yöntemi sonucu elde edilen kriter ağırlıkları değerlerine göre, 0.153 ile "Bebek Ölüm Oranları (K6)" en önemli kriterdir. Daha sonra sırasıyla "Doktor Sayısı (K3), Sağlık Harcamaları (K1), Beklenen Yaşam Süresi (K5), Hemşire Sayısı (K4), Hastane Yatak Sayısı (K2), Tıbbi Teknoloji (K7) ve Tip Mezunları (K8)" gelmektedir.

\subsection{OECD Ülkelerinin Sıralanmalarının EDAS Yöntemi ile Elde Edilmesi}

EDAS yönteminin ilk adımında alternatif ve kriterleri gösteren karar matrisi X, Tablo 7'de görüldüğü gibi oluşturulur. Bu karar matrisinde yer alan veriler OECD ve Dünya Sağlık Örgütü (WHO)'nün internet sitelerinden yararlanılarak elde edilmiştir.

Tablo 7. Karar Matrisi

\begin{tabular}{|c|c|c|c|c|c|c|c|c|}
\hline & Maks. & Maks. & Maks. & Maks. & Maks. & Min. & Maks. & Maks. \\
\hline Ülkeler & $\mathbf{K}_{1}$ & $K_{2}$ & $K_{3}$ & $\mathbf{K}_{4}$ & $\mathrm{~K}_{5}$ & $K_{6}$ & $\mathbf{K}_{7}$ & $\mathbf{K}_{8}$ \\
\hline$w_{j}$ & 0.135 & 0.116 & 0.137 & 0.121 & 0.123 & 0.153 & 0.114 & 0.098 \\
\hline Avustralya & 9.133 & 3.810 & 3.570 & 11.640 & 82.500 & 3.100 & 4.030 & 15.940 \\
\hline Avusturya & 10.321 & 7.420 & 5.130 & 7.990 & 81.700 & 3.100 & 5.410 & 14.090 \\
\hline Belçika & 10.020 & 5.680 & 3.070 & 11.130 & 81.500 & 3.200 & 8.280 & 14.830 \\
\hline Kanada & 10.411 & 2.550 & 2.720 & 9.910 & 81.900 & 4.700 & 8.070 & 7.940 \\
\hline Şili & 8.091 & 2.120 & 1.026 & 5.600 & 79.900 & 6.900 & 0.910 & 8.690 \\
\hline Çek Cum. & 7.115 & 6.850 & 3.690 & 8.070 & 79.100 & 2.800 & 4.860 & 12.660 \\
\hline Danimarka & 10.218 & 2.160 & 3.680 & 16.900 & 80.900 & 3.100 & 9.610 & 22.060 \\
\hline Estonya & 6.719 & 4.760 & 3.460 & 6.100 & 77.800 & 2.300 & 2.330 & 11.480 \\
\hline Finlandiya & 9.227 & 3.970 & 3.210 & 14.260 & 81.500 & 1.900 & 7.370 & 12.030 \\
\hline Fransa & 11.458 & 6.050 & 3.350 & 10.190 & 82.400 & 3.700 & 7.510 & 9.050 \\
\hline Almanya & 11.272 & 8.060 & 4.190 & 12.850 & 81.100 & 3.400 & 6.440 & 11.710 \\
\hline Yunanistan & 8.366 & 4.200 & 6.167 & 3.250 & 81.500 & 4.200 & 4.310 & 9.320 \\
\hline Macaristan & 7.218 & 7.000 & 3.210 & 6.440 & 76.200 & 3.900 & 1.810 & 14.140 \\
\hline İzlanda & 8.486 & 3.110 & 3.930 & 14.710 & 82.300 & 0.700 & 6.070 & 15.800 \\
\hline İrlanda & 7.095 & 2.990 & 3.070 & 11.610 & 81.800 & 3.000 & 3.890 & 24.440 \\
\hline İsrail & 7.372 & 3.020 & 3.080 & 4.990 & 82.500 & 3.100 & 3.360 & 6.760 \\
\hline İtalya & 8.901 & 3.200 & 4.010 & 6.540 & 83.300 & 2.800 & 6.410 & 12.350 \\
\hline Japonya & 10.745 & 13.110 & 2.430 & 11.340 & 84.100 & 2.000 & 7.170 & 6.840 \\
\hline Kore & 7.569 & 11.980 & 2.340 & 6.910 & 82.400 & 2.800 & 3.000 & 7.650 \\
\hline
\end{tabular}




\begin{tabular}{lcccccccc}
\hline Letonya & 6.269 & 5.720 & 3.210 & 4.640 & 74.700 & 3.700 & 5.370 & 17.280 \\
Litvanya & 6.313 & 6.690 & 4.470 & 7.700 & 74.800 & 4.500 & 3.650 & 16.110 \\
Lüksemburg & 6.079 & 4.640 & 2.960 & 11.720 & 82.800 & 3.800 & 3.770 & 0.000 \\
Meksika & 5.404 & 1.520 & 2.360 & 2.890 & 75.400 & 12.100 & 0.540 & 12.620 \\
Hollanda & 10.143 & 3.630 & 3.310 & 12.230 & 81.600 & 3.500 & 7.220 & 14.360 \\
Yeni Zelanda & 9.001 & 2.710 & 3.000 & 10.170 & 81.700 & 5.700 & 6.210 & 9.120 \\
Norvec & 10.369 & 3.690 & 4.680 & 17.730 & 82.500 & 2.200 & 8.130 & 11.140 \\
Polonya & 6.675 & 6.640 & 2.420 & 5.160 & 78.000 & 4.000 & 2.720 & 10.490 \\
Portekiz & 8.985 & 3.420 & 3.868 & 6.470 & 81.200 & 3.200 & 4.050 & 16.440 \\
Slovakya & 7.060 & 5.780 & 3.470 & 5.740 & 77.300 & 5.400 & 4.770 & 13.510 \\
Slovenya & 8.285 & 4.490 & 3.010 & 9.650 & 81.300 & 2.000 & 5.790 & 15.880 \\
İspanya & 8.841 & 2.970 & 3.820 & 5.510 & 83.400 & 2.700 & 4.160 & 13.390 \\
İsvec & 10.916 & 2.340 & 4.270 & 11.060 & 82.400 & 2.500 & 6.900 & 10.160 \\
İsviçre & 12.259 & 4.550 & 4.250 & 17.020 & 83.700 & 3.600 & 9.790 & 10.570 \\
Türkiye & 4.227 & 2.750 & 1.830 & 1.930 & 78.000 & 10.000 & 2.030 & 9.900 \\
İngiltere & 9.687 & 2.580 & 2.820 & 7.860 & 81.200 & 3.800 & 5.040 & 12.870 \\
ABD & 17.150 & 2.800 & 2.580 & 11.610 & 78.600 & 5.900 & 12.370 & 7.550 \\
Ortalama & 8.817 & 4.693 & 3.379 & 9.153 & 80.64 & 3.869 & 5.37 & 12.199 \\
\hline
\end{tabular}

İkinci adımda Eşitlik (6) ile her bir kriter için alternatiflerin göstermiş oldukları performans değerlerinin ortalamaları alınmaktadır.

Tablo 8'de gösterilen her bir kriter için ortalamadan pozitif uzaklık matrisi oluşturulurken kriterlerin fayda ya da maliyet cinsinden oluşuna göre Eşitlik (9) ve Eşitlik (11)'den yararlanılmıştır.

Tablo 8. Ortalama Çözümden Pozitif Uzaklık Matrisi (PDA)

PDA

\begin{tabular}{lcccccccc} 
& $\mathbf{K}_{\mathbf{1}}$ & $\mathbf{K}_{\mathbf{2}}$ & $\mathbf{K}_{\mathbf{3}}$ & $\mathbf{K}_{\mathbf{4}}$ & $\mathbf{K}_{\mathbf{5}}$ & $\mathbf{K}_{\mathbf{6}}$ & $\mathbf{K}_{\mathbf{7}}$ & $\mathbf{K}_{\mathbf{8}}$ \\
\hline Avustralya & 0.036 & 0.000 & 0.056 & 0.272 & 0.023 & 0.199 & 0.000 & 0.307 \\
Avusturya & 0.171 & 0.581 & 0.518 & 0.000 & 0.013 & 0.199 & 0.007 & 0.155 \\
Belçika & 0.136 & 0.210 & 0.000 & 0.216 & 0.011 & 0.173 & 0.542 & 0.216 \\
Kanada & 0.181 & 0.000 & 0.000 & 0.083 & 0.016 & 0.000 & 0.503 & 0.000 \\
Şili & 0.000 & 0.000 & 0.000 & 0.000 & 0.000 & 0.000 & 0.000 & 0.000 \\
Çek Cum. & 0.000 & 0.460 & 0.092 & 0.000 & 0.000 & 0.276 & 0.000 & 0.038 \\
Danimarka & 0.159 & 0.000 & 0.089 & 0.846 & 0.003 & 0.199 & 0.789 & 0.808 \\
Estonya & 0.000 & 0.014 & 0.024 & 0.000 & 0.000 & 0.406 & 0.000 & 0.000 \\
Finlandiya & 0.047 & 0.000 & 0.000 & 0.558 & 0.011 & 0.509 & 0.372 & 0.000 \\
Fransa & 0.300 & 0.289 & 0.000 & 0.113 & 0.022 & 0.044 & 0.398 & 0.000 \\
Almanya & 0.278 & 0.717 & 0.240 & 0.404 & 0.006 & 0.121 & 0.199 & 0.000 \\
Yunanistan & 0.000 & 0.000 & 0.825 & 0.000 & 0.011 & 0.000 & 0.000 & 0.000 \\
Macaristan & 0.000 & 0.491 & 0.000 & 0.000 & 0.000 & 0.000 & 0.000 & 0.159 \\
İlanda & 0.000 & 0.000 & 0.163 & 0.607 & 0.021 & 0.819 & 0.130 & 0.295 \\
İrlanda & 0.000 & 0.000 & 0.000 & 0.268 & 0.014 & 0.225 & 0.000 & 1.003 \\
İsrail & 0.000 & 0.000 & 0.000 & 0.000 & 0.023 & 0.199 & 0.000 & 0.000 \\
İtalya & 0.010 & 0.000 & 0.187 & 0.000 & 0.033 & 0.276 & 0.193 & 0.012 \\
Japonya & 0.219 & 1.793 & 0.000 & 0.239 & 0.043 & 0.483 & 0.335 & 0.000 \\
Kore & 0.000 & 1.553 & 0.000 & 0.000 & 0.022 & 0.276 & 0.000 & 0.000 \\
Letonya & 0.000 & 0.219 & 0.000 & 0.000 & 0.000 & 0.044 & 0.000 & 0.416 \\
Litvanya & 0.000 & 0.425 & 0.323 & 0.000 & 0.000 & 0.000 & 0.000 & 0.321 \\
Lüksemburg & 0.000 & 0.000 & 0.000 & 0.280 & 0.027 & 0.018 & 0.000 & 0.000 \\
& & & & & & & &
\end{tabular}




\begin{tabular}{lllllllll} 
Meksika & 0.000 & 0.000 & 0.000 & 0.000 & 0.000 & 0.000 & 0.000 & 0.034 \\
Hollanda & 0.150 & 0.000 & 0.000 & 0.336 & 0.012 & 0.095 & 0.344 & 0.177 \\
Yeni Zelanda & 0.021 & 0.000 & 0.000 & 0.111 & 0.013 & 0.000 & 0.156 & 0.000 \\
Norveç & 0.176 & 0.000 & 0.385 & 0.937 & 0.023 & 0.431 & 0.514 & 0.000 \\
Polonya & 0.000 & 0.415 & 0.000 & 0.000 & 0.000 & 0.000 & 0.000 & 0.000 \\
Portekiz & 0.019 & 0.000 & 0.145 & 0.000 & 0.007 & 0.173 & 0.000 & 0.348 \\
Slovakya & 0.000 & 0.232 & 0.027 & 0.000 & 0.000 & 0.000 & 0.000 & 0.107 \\
Slovenya & 0.000 & 0.000 & 0.000 & 0.054 & 0.008 & 0.483 & 0.078 & 0.302 \\
İspanya & 0.003 & 0.000 & 0.130 & 0.000 & 0.034 & 0.302 & 0.000 & 0.098 \\
İsveç & 0.238 & 0.000 & 0.264 & 0.208 & 0.022 & 0.354 & 0.285 & 0.000 \\
İsviçre & 0.390 & 0.000 & 0.258 & 0.859 & 0.038 & 0.070 & 0.823 & 0.000 \\
Türkiye & 0.000 & 0.000 & 0.000 & 0.000 & 0.000 & 0.000 & 0.000 & 0.000 \\
İngiltere & 0.099 & 0.000 & 0.000 & 0.000 & 0.007 & 0.018 & 0.000 & 0.055 \\
ABD & 0.945 & 0.000 & 0.000 & 0.268 & 0.000 & 0.000 & 1.303 & 0.000 \\
\hline
\end{tabular}

Bebek ölüm oranları kriteri dışındaki tüm kriterler fayda kriteri olarak belirlenmiştir. Kriterlerin fayda ve maliyet cinsinden oluşuna göre ortalamadan negatif uzaklık matrisi (NDA), Eşitlik (10) ve Eşitlik (12) yardımıyla hesaplanmıştır ve Tablo 9'da gösterilmiştir.

Tablo 9. Ortalama Çözümden Negatif Uzaklık Matrisi (NDA)

NDA

Tablo 9. Ortalama Çözümden Negatif Uzakhk Matrisi (NDA)

\begin{tabular}{lcccccccc}
\hline & $\mathbf{K}_{\mathbf{1}}$ & $\mathbf{K}_{\mathbf{2}}$ & $\mathbf{K}_{\mathbf{3}}$ & $\mathbf{K}_{\mathbf{4}}$ & $\mathbf{K}_{\mathbf{5}}$ & $\mathbf{K}_{\mathbf{6}}$ & $\mathbf{K}_{\mathbf{7}}$ & $\mathbf{K}_{\mathbf{8}}$ \\
\hline Avustralya & 0.000 & 0.188 & 0.000 & 0.000 & 0.000 & 0.000 & 0.250 & 0.000 \\
Avusturya & 0.000 & 0.000 & 0.000 & 0.127 & 0.000 & 0.000 & 0.000 & 0.000 \\
Belçika & 0.000 & 0.000 & 0.092 & 0.000 & 0.000 & 0.000 & 0.000 & 0.000 \\
Kanada & 0.000 & 0.457 & 0.195 & 0.000 & 0.000 & 0.215 & 0.000 & 0.349 \\
Şili & 0.082 & 0.548 & 0.696 & 0.388 & 0.009 & 0.783 & 0.831 & 0.288 \\
Çek Cum. & 0.193 & 0.000 & 0.000 & 0.118 & 0.019 & 0.000 & 0.095 & 0.000 \\
Danimarka & 0.000 & 0.540 & 0.000 & 0.000 & 0.000 & 0.000 & 0.000 & 0.000 \\
Estonya & 0.238 & 0.000 & 0.000 & 0.334 & 0.035 & 0.000 & 0.566 & 0.059 \\
Finlandiya & 0.000 & 0.154 & 0.050 & 0.000 & 0.000 & 0.000 & 0.000 & 0.014 \\
Fransa & 0.000 & 0.000 & 0.009 & 0.000 & 0.000 & 0.000 & 0.000 & 0.258 \\
Almanya & 0.000 & 0.000 & 0.000 & 0.000 & 0.000 & 0.000 & 0.000 & 0.040 \\
Yunanistan & 0.051 & 0.105 & 0.000 & 0.645 & 0.000 & 0.085 & 0.198 & 0.236 \\
Macaristan & 0.181 & 0.000 & 0.050 & 0.296 & 0.055 & 0.008 & 0.663 & 0.000 \\
İzlanda & 0.038 & 0.337 & 0.000 & 0.000 & 0.000 & 0.000 & 0.000 & 0.000 \\
İrlanda & 0.195 & 0.363 & 0.092 & 0.000 & 0.000 & 0.000 & 0.276 & 0.000 \\
İsrail & 0.164 & 0.357 & 0.089 & 0.455 & 0.000 & 0.000 & 0.374 & 0.446 \\
İtalya & 0.000 & 0.318 & 0.000 & 0.286 & 0.000 & 0.000 & 0.000 & 0.000 \\
Japonya & 0.000 & 0.000 & 0.281 & 0.000 & 0.000 & 0.000 & 0.000 & 0.439 \\
Kore & 0.142 & 0.000 & 0.308 & 0.245 & 0.000 & 0.000 & 0.441 & 0.373 \\
Letonya & 0.289 & 0.000 & 0.050 & 0.493 & 0.074 & 0.000 & 0.000 & 0.000 \\
Litvanya & 0.284 & 0.000 & 0.000 & 0.159 & 0.072 & 0.163 & 0.320 & 0.000 \\
Lüksemburg & 0.311 & 0.011 & 0.124 & 0.000 & 0.000 & 0.000 & 0.298 & 1.000 \\
Meksika & 0.387 & 0.676 & 0.302 & 0.684 & 0.065 & 2.127 & 0.899 & 0.000 \\
Hollanda & 0.000 & 0.227 & 0.021 & 0.000 & 0.000 & 0.000 & 0.000 & 0.000 \\
Yeni Zelanda & 0.000 & 0.423 & 0.112 & 0.000 & 0.000 & 0.473 & 0.000 & 0.252 \\
Norveç & 0.000 & 0.214 & 0.000 & 0.000 & 0.000 & 0.000 & 0.000 & 0.087 \\
Polonya & 0.243 & 0.000 & 0.284 & 0.436 & 0.033 & 0.034 & 0.494 & 0.140 \\
Portekiz & 0.000 & 0.271 & 0.000 & 0.293 & 0.000 & 0.000 & 0.246 & 0.000
\end{tabular}




\begin{tabular}{lllllllll} 
Slovakya & 0.199 & 0.000 & 0.000 & 0.373 & 0.041 & 0.396 & 0.112 & 0.000 \\
Slovenya & 0.060 & 0.043 & 0.109 & 0.000 & 0.000 & 0.000 & 0.000 & 0.000 \\
İspanya & 0.000 & 0.367 & 0.000 & 0.398 & 0.000 & 0.000 & 0.225 & 0.000 \\
İsveç & 0.000 & 0.501 & 0.000 & 0.000 & 0.000 & 0.000 & 0.000 & 0.167 \\
İsviçre & 0.000 & 0.031 & 0.000 & 0.000 & 0.000 & 0.000 & 0.000 & 0.134 \\
Türkiye & 0.521 & 0.414 & 0.458 & 0.789 & 0.033 & 1.584 & 0.622 & 0.188 \\
İngiltere & 0.000 & 0.450 & 0.166 & 0.141 & 0.000 & 0.000 & 0.062 & 0.000 \\
ABD & 0.000 & 0.403 & 0.237 & 0.000 & 0.025 & 0.525 & 0.000 & 0.381 \\
\hline
\end{tabular}

Dördüncü adımda SWARA yöntemi ile belirlenen kriter ağırlıkları kullanılarak tüm alternatifler için PDA ve NDA'nın ağırlıklı toplam değerleri Eşitlik (13) ve Eşitlik (14) ile hesaplanmıştır. Daha sonra Eşitlik (15) ve Eşitlik (16) kullanılarak $S P_{i}$ ve $S N_{i}$ değerlerinin normalizasyon işlemi gerçekleştirilmiştir. Tablo 10 'da hesaplanmış olan ağırlıklı toplam pozitif $S P_{i}$ ve ağırlıklı toplam negatif $S N_{i}$ değerleri ile bunların normalize edilmiş halleri $N S P_{i}$ ve $N S N_{i}$ ve son olarak tüm alternatifler için hesaplanan değerlendirme puanları $A S_{i}$ gösterilmiştir.

Tablo 10. EDAS Yöntemi Kullanılarak EIde Edilen Sonuçlar

\begin{tabular}{|c|c|c|c|c|c|c|}
\hline Ülkeler & $\mathbf{S P}_{\mathbf{i}}$ & $\mathbf{S N}_{\mathrm{i}}$ & $\mathbf{N S P}_{\mathbf{i}}$ & $\mathbf{N S N}_{i}$ & $\mathbf{A} \mathbf{S}_{\mathbf{i}}$ & Ülke Sıralamaları \\
\hline Avustralya & 0.109 & 0.050 & 0.283 & 0.927 & 0.605 & 18 \\
\hline Avusturya & 0.209 & 0.015 & 0.546 & 0.978 & 0.762 & 7 \\
\hline Belçika & 0.180 & 0.013 & 0.468 & 0.982 & 0.725 & 10 \\
\hline Kanada & 0.094 & 0.147 & 0.244 & 0.788 & 0.516 & 24 \\
\hline Şili & 0.000 & 0.461 & 0.000 & 0.333 & 0.166 & 34 \\
\hline Çek Cum & 0.112 & 0.054 & 0.291 & 0.922 & 0.607 & 17 \\
\hline Danimarka & 0.336 & 0.063 & 0.876 & 0.909 & 0.892 & 2 \\
\hline Estonya & 0.067 & 0.147 & 0.174 & 0.787 & 0.481 & 27 \\
\hline Finlandiya & 0.195 & 0.026 & 0.509 & 0.962 & 0.736 & 9 \\
\hline Fransa & 0.142 & 0.026 & 0.371 & 0.962 & 0.666 & 12 \\
\hline Almanya & 0.244 & 0.004 & 0.637 & 0.994 & 0.816 & 6 \\
\hline Yunanistan & 0.114 & 0.156 & 0.298 & 0.774 & 0.536 & 22 \\
\hline Macaristan & 0.073 & 0.151 & 0.189 & 0.782 & 0.485 & 26 \\
\hline İzlanda & 0.267 & 0.044 & 0.697 & 0.936 & 0.816 & 5 \\
\hline İrlanda & 0.167 & 0.112 & 0.435 & 0.837 & 0.636 & 15 \\
\hline İsrail & 0.033 & 0.217 & 0.087 & 0.686 & 0.386 & 33 \\
\hline İtalya & 0.096 & 0.071 & 0.251 & 0.897 & 0.574 & 19 \\
\hline Japonya & 0.384 & 0.082 & 1.000 & 0.882 & 0.941 & 1 \\
\hline Kore & 0.225 & 0.178 & 0.586 & 0.743 & 0.665 & 13 \\
\hline Letonya & 0.073 & 0.115 & 0.190 & 0.834 & 0.512 & 25 \\
\hline Litvanya & 0.125 & 0.128 & 0.326 & 0.815 & 0.570 & 20 \\
\hline Lüksemburg & 0.040 & 0.192 & 0.104 & 0.722 & 0.413 & 32 \\
\hline Meksika & 0.003 & 0.691 & 0.009 & 0.000 & 0.004 & 36 \\
\hline Hollanda & 0.134 & 0.029 & 0.348 & 0.958 & 0.653 & 14 \\
\hline Yeni Zelanda & 0.036 & 0.162 & 0.093 & 0.766 & 0.430 & 30 \\
\hline
\end{tabular}




\begin{tabular}{llllllc} 
Norveç & 0.317 & 0.033 & 0.827 & 0.952 & 0.889 & 3 \\
Polonya & 0.048 & 0.204 & 0.125 & 0.705 & 0.415 & 31 \\
Portekiz & 0.084 & 0.095 & 0.218 & 0.863 & 0.540 & 21 \\
Slovakya & 0.041 & 0.150 & 0.107 & 0.782 & 0.445 & 29 \\
Slovenya & 0.120 & 0.028 & 0.313 & 0.959 & 0.636 & 16 \\
İspanya & 0.078 & 0.116 & 0.204 & 0.831 & 0.518 & 23 \\
İsvec & 0.183 & 0.075 & 0.476 & 0.892 & 0.684 & 11 \\
İsviçre & 0.301 & 0.017 & 0.784 & 0.976 & 0.880 & 4 \\
Türkiye & 0.000 & 0.612 & 0.000 & 0.113 & 0.057 & 35 \\
İngiltere & 0.022 & 0.099 & 0.058 & 0.857 & 0.457 & 28 \\
ABD & 0.309 & 0.200 & 0.804 & 0.711 & 0.757 & 8 \\
\hline
\end{tabular}

Sonuç olarak EDAS yöntemi ile elde edilen ülke sıralamaları Tablo 10'da yer almıştır. Bu sıralamaya göre Japonya, Danimarka, Norveç ilk üç sırada yer alırken, Şili, Türkiye ve Meksika son sıralarda yer almaktadır.

\subsection{OECD Ülkelerinin Sıralamalarının ARAS Yöntemi ile Elde Edilmesi}

İlk olarak karar matrisi oluşturulur ve kriterlerin fayda veya maliyet cinsinden oluşu belirlenir. Eğer kriterlerin Xo yani optimal değerleri bilinmiyorsa Eşitlik (19) ve Eşitlik (20)'de belirtildiği gibi optimal değeri fayda kriterleri için maksimum değerlendirme puanı, maliyet kriterleri için ise minimum değerlendirme puanı kabul edilir. İlk adımda Tablo 7'de yer alan karar matrisinden yararlanılarak fayda kriteri olarak belirlenmiş olan sağlık harcamaları, hastane yatak sayısı, doktor sayısı, hemşire sayısı, beklenen yaşam süresi, tıbbi teknoloji ve tıp mezunları kriterleri için maksimum değerlendirme puanları, maliyet kriteri olarak belirlenmiş olan bebek ölüm kriteri için ise minimum değerlendirme puanı belirlenmiştir. İkinci adımda Eşitlik (21) ve Eşitlik (22) yardımıyla kriterler fayda ya da maliyet cinsinden oluşuna göre normalizasyon işlemi gerçekleştirilir. Normalize karar matrisi Tablo 11'de gösterilmektedir.

Tablo 11. Normalize Karar Matrisi

\begin{tabular}{lcccccccc}
\hline Ülkeler & $\mathbf{K}_{\mathbf{1}}$ & $\mathbf{K}_{\mathbf{2}}$ & $\mathbf{K}_{\mathbf{3}}$ & $\mathbf{K}_{\mathbf{4}}$ & $\mathbf{K}_{\mathbf{5}}$ & $\mathbf{K}_{\mathbf{6}}$ & $\mathbf{K}_{\mathbf{7}}$ & $\mathbf{K}_{\mathbf{8}}$ \\
\hline Optimal & 0.051 & 0.072 & 0.048 & 0.051 & 0.028 & 0.107 & 0.060 & 0.053 \\
\hline Avustralya & 0.027 & 0.021 & 0.028 & 0.034 & 0.028 & 0.024 & 0.020 & 0.034 \\
Avusturya & 0.031 & 0.041 & 0.040 & 0.023 & 0.027 & 0.024 & 0.026 & 0.030 \\
Belçika & 0.030 & 0.031 & 0.024 & 0.032 & 0.027 & 0.023 & 0.040 & 0.032 \\
Kanada & 0.031 & 0.014 & 0.021 & 0.029 & 0.027 & 0.016 & 0.039 & 0.017 \\
Şili & 0.024 & 0.012 & 0.008 & 0.016 & 0.027 & 0.011 & 0.004 & 0.019 \\
Çek Cum. & 0.021 & 0.038 & 0.029 & 0.023 & 0.026 & 0.027 & 0.024 & 0.027 \\
Danimarka & 0.031 & 0.012 & 0.029 & 0.049 & 0.027 & 0.024 & 0.047 & 0.048 \\
Estonya & 0.020 & 0.026 & 0.027 & 0.018 & 0.026 & 0.033 & 0.011 & 0.025 \\
Finlandiya & 0.028 & 0.022 & 0.025 & 0.041 & 0.027 & 0.039 & 0.036 & 0.026 \\
Fransa & 0.034 & 0.033 & 0.026 & 0.029 & 0.028 & 0.020 & 0.037 & 0.020 \\
Almanya & 0.034 & 0.044 & 0.033 & 0.037 & 0.027 & 0.022 & 0.031 & 0.025 \\
Yunanistan & 0.025 & 0.023 & 0.048 & 0.009 & 0.027 & 0.018 & 0.021 & 0.020 \\
Macaristan & 0.022 & 0.038 & 0.025 & 0.019 & 0.026 & 0.019 & 0.009 & 0.030 \\
İzlanda & 0.025 & 0.017 & 0.031 & 0.042 & 0.028 & 0.107 & 0.030 & 0.034 \\
İrlanda & 0.021 & 0.016 & 0.024 & 0.033 & 0.027 & 0.025 & 0.019 & 0.053 \\
İsrail & 0.022 & 0.017 & 0.024 & 0.014 & 0.028 & 0.024 & 0.016 & 0.015
\end{tabular}




\begin{tabular}{lllllllll} 
İtalya & 0.027 & 0.018 & 0.031 & 0.019 & 0.028 & 0.027 & 0.031 & 0.027 \\
Japonya & 0.032 & 0.072 & 0.019 & 0.033 & 0.028 & 0.038 & 0.035 & 0.015 \\
Kore & 0.023 & 0.066 & 0.018 & 0.020 & 0.028 & 0.027 & 0.015 & 0.017 \\
Letonya & 0.019 & 0.031 & 0.025 & 0.013 & 0.025 & 0.020 & 0.026 & 0.037 \\
Litvanya & 0.019 & 0.037 & 0.035 & 0.022 & 0.025 & 0.017 & 0.018 & 0.035 \\
Lüksemburg & 0.018 & 0.025 & 0.023 & 0.034 & 0.028 & 0.020 & 0.018 & 0.000 \\
Meksika & 0.016 & 0.008 & 0.018 & 0.008 & 0.025 & 0.006 & 0.003 & 0.027 \\
Hollanda & 0.030 & 0.020 & 0.026 & 0.035 & 0.027 & 0.021 & 0.035 & 0.031 \\
Yeni Zelanda & 0.027 & 0.015 & 0.023 & 0.029 & 0.027 & 0.013 & 0.030 & 0.020 \\
Norvec & 0.031 & 0.020 & 0.037 & 0.051 & 0.028 & 0.034 & 0.040 & 0.024 \\
Polonya & 0.020 & 0.036 & 0.019 & 0.015 & 0.026 & 0.019 & 0.013 & 0.023 \\
Portekiz & 0.027 & 0.019 & 0.030 & 0.019 & 0.027 & 0.023 & 0.020 & 0.035 \\
Slovakya & 0.021 & 0.032 & 0.027 & 0.017 & 0.026 & 0.014 & 0.023 & 0.029 \\
Slovenya & 0.025 & 0.025 & 0.024 & 0.028 & 0.027 & 0.038 & 0.028 & 0.034 \\
İspanya & 0.026 & 0.016 & 0.030 & 0.016 & 0.028 & 0.028 & 0.020 & 0.029 \\
İsveç & 0.033 & 0.013 & 0.033 & 0.032 & 0.028 & 0.030 & 0.034 & 0.022 \\
İsviçre & 0.037 & 0.025 & 0.033 & 0.049 & 0.028 & 0.021 & 0.048 & 0.023 \\
Türkiye & 0.013 & 0.015 & 0.014 & 0.006 & 0.026 & 0.008 & 0.010 & 0.021 \\
İngiltere & 0.029 & 0.014 & 0.022 & 0.023 & 0.027 & 0.020 & 0.024 & 0.028 \\
ABD & 0.051 & 0.015 & 0.020 & 0.033 & 0.026 & 0.013 & 0.060 & 0.016 \\
\hline
\end{tabular}

Belirlenmiş olan kriter ağırlıkları ile her bir alternatifin kriterde göstermiş olduğu performans değeri çarpılarak ağırlıklı normalizasyon matrisi Eşitlik (23) kullanılarak elde edilmiş ve Tablo 12'de gösterilmiştir.

Tablo 12. Ă̆ırlıklı Normalize Karar Matrisi

\begin{tabular}{lcccccccc}
\hline Ülkeler & $\mathbf{K}_{\mathbf{1}}$ & $\mathbf{K}_{\mathbf{2}}$ & $\mathbf{K}_{\mathbf{3}}$ & $\mathbf{K}_{\mathbf{4}}$ & $\mathbf{K}_{\mathbf{5}}$ & $\mathbf{K}_{\mathbf{6}}$ & $\mathbf{K}_{\mathbf{7}}$ & $\mathbf{K}_{\mathbf{8}}$ \\
\hline Optimal & 0.007 & 0.008 & 0.007 & 0.006 & 0.003 & 0.016 & 0.007 & 0.005 \\
Avustralya & 0.004 & 0.002 & 0.004 & 0.004 & 0.003 & 0.004 & 0.002 & 0.003 \\
Avusturya & 0.004 & 0.005 & 0.005 & 0.003 & 0.003 & 0.004 & 0.003 & 0.003 \\
Belçika & 0.004 & 0.004 & 0.003 & 0.004 & 0.003 & 0.004 & 0.005 & 0.003 \\
Kanada & 0.004 & 0.002 & 0.003 & 0.003 & 0.003 & 0.002 & 0.004 & 0.002 \\
Şili & 0.003 & 0.001 & 0.001 & 0.002 & 0.003 & 0.002 & 0.001 & 0.002 \\
Çek Cum. & 0.003 & 0.004 & 0.004 & 0.003 & 0.003 & 0.004 & 0.003 & 0.003 \\
Danimarka & 0.004 & 0.001 & 0.004 & 0.006 & 0.003 & 0.004 & 0.005 & 0.005 \\
Estonya & 0.003 & 0.003 & 0.004 & 0.002 & 0.003 & 0.005 & 0.001 & 0.002 \\
Finlandiya & 0.004 & 0.003 & 0.003 & 0.005 & 0.003 & 0.006 & 0.004 & 0.003 \\
Fransa & 0.005 & 0.004 & 0.004 & 0.004 & 0.003 & 0.003 & 0.004 & 0.002 \\
Almanya & 0.005 & 0.005 & 0.004 & 0.004 & 0.003 & 0.003 & 0.004 & 0.002 \\
Yunanistan & 0.003 & 0.003 & 0.007 & 0.001 & 0.003 & 0.003 & 0.002 & 0.002 \\
Macaristan & 0.003 & 0.004 & 0.003 & 0.002 & 0.003 & 0.003 & 0.001 & 0.003 \\
İzlanda & 0.003 & 0.002 & 0.004 & 0.005 & 0.003 & 0.016 & 0.003 & 0.003 \\
İlanda & 0.003 & 0.002 & 0.003 & 0.004 & 0.003 & 0.004 & 0.002 & 0.005 \\
İsrail & 0.003 & 0.002 & 0.003 & 0.002 & 0.003 & 0.004 & 0.002 & 0.001 \\
İtalya & 0.004 & 0.002 & 0.004 & 0.002 & 0.003 & 0.004 & 0.004 & 0.003 \\
Japonya & 0.004 & 0.008 & 0.003 & 0.004 & 0.003 & 0.006 & 0.004 & 0.001 \\
Kore & 0.003 & 0.008 & 0.003 & 0.002 & 0.003 & 0.004 & 0.002 & 0.002 \\
Letonya & 0.003 & 0.004 & 0.003 & 0.002 & 0.003 & 0.003 & 0.003 & 0.004 \\
Litvanya & 0.003 & 0.004 & 0.005 & 0.003 & 0.003 & 0.003 & 0.002 & 0.003 \\
\hline 930 & & & & & & & &
\end{tabular}




\begin{tabular}{lllllllll}
\hline Lüksemburg & 0.002 & 0.003 & 0.003 & 0.004 & 0.003 & 0.003 & 0.002 & 0.000 \\
Meksika & 0.002 & 0.001 & 0.003 & 0.001 & 0.003 & 0.001 & 0.000 & 0.003 \\
Hollanda & 0.004 & 0.002 & 0.004 & 0.004 & 0.003 & 0.003 & 0.004 & 0.003 \\
Yeni Zelanda & 0.004 & 0.002 & 0.003 & 0.004 & 0.003 & 0.002 & 0.003 & 0.002 \\
Norvec & 0.004 & 0.002 & 0.005 & 0.006 & 0.003 & 0.005 & 0.005 & 0.002 \\
Polonya & 0.003 & 0.004 & 0.003 & 0.002 & 0.003 & 0.003 & 0.002 & 0.002 \\
Portekiz & 0.004 & 0.002 & 0.004 & 0.002 & 0.003 & 0.004 & 0.002 & 0.003 \\
Slovakya & 0.003 & 0.004 & 0.004 & 0.002 & 0.003 & 0.002 & 0.003 & 0.003 \\
Slovenya & 0.003 & 0.003 & 0.003 & 0.003 & 0.003 & 0.006 & 0.003 & 0.003 \\
İspanya & 0.004 & 0.002 & 0.004 & 0.002 & 0.003 & 0.004 & 0.002 & 0.003 \\
İsveç & 0.004 & 0.001 & 0.005 & 0.004 & 0.003 & 0.005 & 0.004 & 0.002 \\
İsviçre & 0.005 & 0.003 & 0.005 & 0.006 & 0.003 & 0.003 & 0.005 & 0.002 \\
Türkiye & 0.002 & 0.002 & 0.002 & 0.001 & 0.003 & 0.001 & 0.001 & 0.002 \\
İngiltere & 0.004 & 0.002 & 0.003 & 0.003 & 0.003 & 0.003 & 0.003 & 0.003 \\
ABD & 0.007 & 0.002 & 0.003 & 0.004 & 0.003 & 0.002 & 0.007 & 0.002 \\
\hline
\end{tabular}

Bir sonraki adımda Eşitlik (25) kullanılarak Si değerleri hesaplanmıştır. Buradaki $S_{i}$, her bir alternatifin optimizasyon fonksiyon değerini göstermektedir. Daha sonra fayda değerini gösteren $K_{i}$ değeri Eşitlik (26) yardımıyla hesaplanmıştır. Tablo 13 'te $S_{i}, K_{i}$ değerleri gösterilmektedir. $K_{i}$ değerleri azalan düzeyde siralanarak ülkelerin performans sıralamaları gerçekleştirilmiştir.

Tablo 13. ARAS Yöntemi Kullanılarak Elde Edilen Sonuçlar

\begin{tabular}{|c|c|c|c|}
\hline Ülkeler & $S_{i}$ & $\boldsymbol{K}_{i}$ & Suralama \\
\hline Optimal & 0.060 & 1.000 & \\
\hline Avustralya & 0.027 & 0.445 & 16 \\
\hline Avusturya & 0.030 & 0.504 & 8 \\
\hline Belçika & 0.029 & 0.492 & 9 \\
\hline Kanada & 0.024 & 0.403 & 24 \\
\hline Şili & 0.015 & 0.250 & 34 \\
\hline Çek Cum. & 0.027 & 0.446 & 15 \\
\hline Danimarka & 0.032 & 0.540 & 5 \\
\hline Estonya & 0.023 & 0.392 & 26 \\
\hline Finlandiya & 0.031 & 0.512 & 7 \\
\hline Fransa & 0.028 & 0.470 & 13 \\
\hline Almanya & 0.031 & 0.524 & 6 \\
\hline Yunanistan & 0.024 & 0.404 & 23 \\
\hline Macaristan & 0.023 & 0.386 & 28 \\
\hline İzlanda & 0.041 & 0.688 & 1 \\
\hline İrlanda & 0.027 & 0.444 & 17 \\
\hline İsrail & 0.020 & 0.339 & 33 \\
\hline İtalya & 0.026 & 0.432 & 19 \\
\hline Japonya & 0.034 & 0.565 & 2 \\
\hline Kore & 0.026 & 0.440 & 18 \\
\hline Letonya & 0.024 & 0.401 & 25 \\
\hline Litvanya & 0.025 & 0.423 & 20 \\
\hline Lüksemburg & 0.021 & 0.353 & 31 \\
\hline Meksika & 0.014 & 0.229 & 35 \\
\hline Hollanda & 0.028 & 0.465 & 14 \\
\hline
\end{tabular}




\begin{tabular}{lccc} 
Yeni Zelanda & 0.023 & 0.381 & 30 \\
Norvec & 0.033 & 0.554 & 3 \\
Polonya & 0.021 & 0.352 & 32 \\
Portekiz & 0.025 & 0.415 & 21 \\
Slovakya & 0.023 & 0.385 & 29 \\
Slovenya & 0.028 & 0.475 & 11 \\
İspanya & 0.024 & 0.405 & 22 \\
İsveç & 0.028 & 0.472 & 12 \\
İsviçre & 0.033 & 0.544 & 36 \\
Türkiye & 0.014 & 0.228 & 27 \\
İngiltere & 0.023 & 0.387 & 10 \\
ABD & 0.029 & 0.486 & \\
\hline
\end{tabular}

ARAS Yöntemi kullanılarak elde edilen sıralama sonuçlarına göre en iyi performans gösteren üç ülke; İzlanda, Japonya ve Norveç olurken, en kötü performansı sergileyen üç ülke; Şili, Meksika ve Türkiye olmuştur.

EDAS ve ARAS yöntemleri sonucu elde edilen sıralamalar arasındaki ilişkiyi belirlemek için Spearman korelasyon katsayısından yararlanılmış ve bu katsayı değeri 0.997 olarak hesaplanmıştır. Buna göre, kullanılan iki yöntem arasındaki ilişkilerin yüksek olduğu ve elde edilen sıralamaların birbiriyle uyum içerisinde olduğu söylenebilir.

\section{SONUÇ}

Sağlık sektörünün yapısı ve mevcut durumu, ülkelerin gelişmişlik düzeylerini gösteren ve insanların yaşam kalitesini etkileyen en önemli ölçütlerden biri olarak kabul edilmektedir. Sağlık sektörünün yapısını etkileyen nedenlerden bazıları, ülkelerin ekonomileri, izledikleri politikalar, nüfus yapıları, teknolojik gelişmeleri takip etme olarak sıralanabilir. Ülkeler arasında değişiklik gösteren bu unsurlar ile birlikte ülkelerin sağlık sektör yapısı da farklılık göstermektedir. Ülkelerin sağlık göstergeleri açısından diğer ülkelere göre konumlarını belirlemeleri ve elde edilen sonuçlara göre iyileştirici tedbirler almaları önem arz etmektedir.

$\mathrm{Bu}$ çalışmada, sağlık göstergeleri açısından OECD’ye üye 36 ülkenin sıralamaları elde edilmiştir. Sağllk göstergelerinin önem düzeyleri belirlenirken SWARA yönteminden yararlanılmış, ülkelerin sıralamasına ise EDAS ve ARAS yöntemleri ile ulaşılmıştır. Öncelikle, SWARA yöntemi ile sağlık göstergelerinin önem düzeyleri belirlenmiştir. "Bebek Ölüm Oranları (K6)" 0.153 ağırlığı ile en yüksek öneme sahiptir. Onu, "Doktor Sayısı (K3), Sağlık Harcamaları (K1), Beklenen Yaşam Süresi (K5), Hemşire Sayısı (K4), Hastane Yatak Sayısı (K2), Tıbbi Teknoloji (K7) ve Tıp Mezunları (K8)" kriterleri izlemektedir.

EDAS yöntemi yardımıyla ulaşılan sıralama sonuçlarında ilk beşte Japonya, Danimarka, Norveç, İsviçre, İzlanda yer alırken, son beşte, Lüksemburg, İsrail, Şili, Türkiye, Meksika yer almıştır. ARAS yöntemi ile elde edilen sıralamalarda yer alan ilk beş ülke sırasıyla İzlanda, Japonya, Norveç, İsviçre, Danimarka olurken, son sıralamada yer alan ülkeler Polonya, İsrail, Şili, Meksika ve Türkiye olmuştur. EDAS ve ARAS yöntemleri ile elde edilen sonuçlara göre, ilk beşte yer alan olan ülkelerin, sıralamaları farklı olsa da aynı ülkeler olduğu görülmektedir. Ayrıca, son sıralarda yer alan olan ülkeler de benzerlik göstermektedir. İki yöntem arasındaki ilişkiyi belirlemek için Spearman korelasyon katsayısı hesaplanmış ve 0.99 'un üzerinde elde edilmiştir. EDAS ve ARAS yöntemlerinin sağlık gösterge kriterleri altında ülkelerin sıralamasını belirlemek için etkin sonuçlar verdiği tespit edilmiştir. 
Bu çalışma sonucunda Türkiye'nin belirlenen sağlık göstergeleri altında OECD ülkeleri içinde alt sıralarda yer aldığı görülmüştür. Son sıralarda yer alan diğer bir ülke olan Meksika'nın özellikle bebek ölüm oranlarının yüksek olduğu görülmektedir. Bebek ölüm oranlarının yüksek olmasındaki nedenler, bebeklerin gerek anne karnında gerekse doğduktan sonra besinleri yeterli düzeyde alamamaları ve annelerin eğitim seviyesinin düşük olması olarak verilebilir. $\mathrm{Bu}$ besinlere ulaşamamalarındaki temel neden ekonomik durumun iyi olmamasıdır. Bebek ölüm oranları, ülkelerin sağlık hizmetlerinin düzeyini temsil etmesi açısından önemli bir sağlık göstergesidir. İlk sıralarda yer alan Japonya, Danimarka, Norveç, İsviçre, İzlanda gibi ülkelerde beklenen yaşam süresinin uzun olduğu görülmektedir. Beklenen yaşam süresinin uzunluğu ülkelerin ekonomik açıdan gelişmiş olduğunu göstermektedir. Son siralarda yer alan Meksika, Türkiye ve Polonya gibi ülkelerin beklenen yaşam süresinin, OECD ülke ortalamasının altında yer aldığı görülmektedir. Az gelişmiş ve gelişmekte olan toplumlarda beklenen yaşam süresi gelişmiş ülkelere göre daha düşüktür. Sağlık koşullarının iyileştirilmesiyle, beklenen yaşam süresinin uzatılması mümkün olacaktır. Ekonominin iyi olduğu ülkelerde, sağlık harcamalarının payı da yüksek olmaktadır. Sıralama sonuçları da dikkate alındığında, ilk sıralarda yer alan ülkelerin sağlık harcamalarına ayırdığı payın yüksek olduğu görülmektedir. Son sıralarda yer alan ülkeler, sağlık harcamalarını arttırarak sağlık alanında daha iyi konuma sahip olabileceklerdir. Sıralamada sonlarda yer alan ülkelerin ve sağlık hizmetlerinin gelişmesi ve sağlık göstergelerinin iyileştirilmesi için sağlık personel sayılarının, hastane yataklarının ve tıbbi cihaz sayılarının arttırılması gerekmektedir. Bunların yanında sağlık alanında yapılan harcamaların ve kaynakların da arttırılması ile sağlık hizmetleri iyileştirilebilecektir.

Bundan sonraki çalışmalarda, diğer ÇKKV yöntemleri ile OECD ülkeleri arasındaki sıralamalar elde edilebilir. Ayrıca farklı sağlık göstergeleri dikkate alınarak sıralamalardaki değişiklikler gözlemlenebilir.

\section{KAYNAKÇA}

AFONSO, A., \& AUBYN, M. (2006). "Relative Efficiency of Health Provision: A DEA Approach With Non-Discretionary Inputs". Working Papers, Department of Economics At The School of Economics And Management (ISEG), Technical University of Lisbon.

AFONSO, A., \& ST AUBYN, M. (2005). "Non-Parametric Approaches to Education and Health Efficiency in OECD Countries". Journal of Applied Economics, 8(2): 227-246.

ALBAYRAK, Ö., \& ERKAYMAN, B. (2018). "Bulanık DEMATEL ve EDAS Yöntemleri Kullanılarak Sporcular İçin Akıllı Bileklik Seçimi". Ergonomi, 1(1): 92-102.

ALPTEKİN, N., \& YEŞİLAYDIN, G. (2015). "OECD Ülkelerinin Sağlık Göstergelerine Göre Bulanık Kümeleme Analizi ile Sınıflandırılması". İşletme Araştırmaları Dergisi, 7(4): 137-155.

ARSLAN, H.M. (2017). "Determination of Optimal Vehicle Selection of Logistics Companies with AHP ARAS Hybrid Method". Alphanumeric Journal, 5(2): 271-282.

ARSLAN, H.M. (2018). "AHP ve EDAS Yöntemleri ile Döşemelik Kadife Üretim İşletmelerinde En Verimli Dokuma Makinesi Seçimi". II. Uluslararası Multidispliner Çalışmaları Kongresi, Adana. 
AYYILDIZ, E., \& DEMIRCİ E. (2018). "Türkiye'de Yer Alan Şehirlerin Yaşam Kalitelerinin SWARA Entegreli TOPSIS Yöntemi ile Belirlenmesi", Pamukkale Üniversitesi Sosyal Bilimler Enstitüsü Dergisi, 30: 67-87.

BAKIR, M., \& ATALIK, Ö. (2018). "ENTROPI ve ARAS Yöntemleriyle Havayolu İşletmelerinde Hizmet Kalitesinin Değerlendirilmesi".Journal of Business ResearchTürk, 10(1): 617-638.

BALEZENTIENE, L., \& KUSTA A. (2012). "Reducing Greenhouse Gas Emissions in Grassland Ecosystems of The Central Lithuania:Multi-Criteria Evaluation on a basis of the ARAS Method".The Scientific World Journal, Volume 2012: 1-11.

CHATTERJEE, P., BANERJEE, A., MONDAL, S., BORAL, S., \& CHAKRABORTY, S. (2018). "Development of A Hybrid Meta-Model for Material Selection Using Design Experiments and EDAS Method". Engineering Transactions, 66(2):187-207.

CHU NG, Y. (2008)."The Productive Efficiency of The Health Care Sector of China". The Review of Regional Studies, 38(3): 381-393.

ÇAKIR, E. (2017). "Kentsel Dönüşüm Kapsamında Müteahhit Firmanın SWARA- Gri İlişkisel Analiz Yöntemiyle Seçilmesi". Uluslararası Bilimsel Araştırmalar Dergisi, 2(6): 79-95.

ÇAKIR, E., \& AKAR, G. S. (2017). "Bütünleşik TOPSIS ve SWARA Yöntemi ile Makine Seçimi: Bir Üretim İşletmesinde Uygulama". International Journal of Akademic Value Studies, 3(13): 206-216.

ÇAKIR, E., \& KARABIYIK, K.B. (2017). "Bütünleşik SWARA-COPRAS Yöntemi Kullanarak Bulut Depolama Hizmet Sağlayıcılarının Değerlendirilmesi". Bilişim Teknolojileri Dergisi, 10(4): 417-434.

ÇAKIR, E. (2018a). "Elektronik Belge Yönetim Sistemi (EBYS) Yazılımı Seçiminde Çok Kriterli Karar Verme Yöntemleri: Bir Belediye Örneği".Business, Economics and Management Research Journal- BEMAREJ, 1(1): 15-30.

ÇAKIR, E. (2018b). "Bütünleşik SWARA ve EDAS Yöntemi Kullanarak Fitness Merkezlerinin Değerlendirilmesi: Örnek Bir Uygulama". Hitit Üniversitesi Sosyal Bilimler Enstitüsü Dergisi, 11(3): 1907- 1923.

DARJI, V.P., \& RAO, R.V. (2014). "Intelligent Multi Criteria Decision Making Methods for Material Selection in Sugar Industry". Procedia Materials Science, 5: 2585 - 2594.

ECER, F. (2016). "ARAS Yöntemi Kullanılarak Kurumsal Kaynak Planlaması Yazılımı Seçimi".Uluslararası Alanya İşletme Fakültesi Dergisi, 8(1): 89-98.

ECER, F. (2017). "Third-Party Logistics (3pls) Provider Selection via fuzzy AHP and EDAS Integrated Model". Technological and Economic Development of Economy, 24(2): 615-634.

ERCAN, E., \& KUNDAKCI, N. (2017). "Bir Tekstil İşletmesi için Desen Programı Seçiminde ARAS ve OCRA Yöntemlerinin Karşılaştırılması". Afyon Kocatepe Üniversitesi Sosyal Bilimler Dergisi, 19(1): 83-105. 
ERSÖZ, F. (2009). “Türkiye ile OECD’ye Üye Ülkelerin Seçilmiş Sağlık Göstergelerinin Kümeleme ve Ayırma Analizi ile Karşılaştırılması”. Türkiye Klinikleri Tıp Bilimleri Dergisi, 29(6): 1650-1659.

GENÇ, A., AVCI, T., \& SEVGIN, H. (2017). "Karadeniz Ekonomik İşbirliği Üye Ülkelerine İlişkin Etkinlik Analizi: TOPSIS, ARAS ve MOORA Yöntemleriyle Bir Uygulama".Pamukkale Journal of Eurasian Socieconomic Studies, 4(2): 15-40.

GHORSHI NEZHAD, M.R., ZOLFANI, S.H., MOZTARZADEH, F., ZAVADSKAS, E.K., \& BAHRAMIM. (2015). "Planning the Priority of High Tech Industries based on SWARA-WASPAS Methodology: The Case of the Nano Technology in İran". Ekonomska istrazivanja, 28(1): 1111-1137.

GIRGINER, N. (2013). "A Comparison of the Healthcare Indicators of Turkey and The European Union Members Countries Using Multidimensional Scaling Analysis and Cluster Analysis". İktisat İşletme ve Finans, 28(323): 55-72.

GÖZTEPE, B. H. (2017). Çok Kriteli Karar Verme Yöntemlerini Kullanarak OECD'ye Üye Ülkelerin Sağlık Göstergeleri ile Değerlendirilmesi, Yüksek Lisans Tezi, Sosyal Bilimler Enstitüsü Ekonometri Anabilim Dalı, Antalya.

JUODAGALVIENĖ, B., TURSKIS, Z., ŠAPARAUSKAS, J., \& ENDRIUKAITYTĖ, A. (2017). "Integrated Multi-Criteria Evaluation of House's Plan Shape Based on the EDAS and SWARA Methods". Engineering Structures and Technologies, 9(3): 117 125.

KARABAŠEVIĆ, D., STANUJKIĆ D., \& UROŠEVIĆ S. (2015). "The MCDM Model for Personnel Selection Based on SWARA and ARAS Methods". Management, 43-52.

KARABAŠEVIĆ, D., ZAVADSKAS, E.K., STANUJKIC, D., POPOVIC, G., \& BRZAKOVIC, M. (2018). "An Approach to Personnel Selection in the IT Industry based on the EDAS Method". Transformations in Business \& Economics, 17(2): 5465 .

KERŠULIENĖ, V., ZAVADSKAS, E. K., \& TURSKIS, Z. (2010). "Selection of Rational Dispute Resolution Method by Applying New Step-Wise Weight Assessment Ratio Analysis (SWARA)". Journal of Business Economics and Management, 11(2): 243258.

KESHAVARZ GHORABAEE, M., ZAVADSKAS, E. K., OLFAT, L., \& TURSKIS, Z. (2015). "Multi-Criteria Inventory Classification Using a New Method of Evaluation Based on Distance from Average Solution (EDAS)". Informatica, 26(3): 435-451.

KESHAVARZ GHORABAEEA M., AMIRIA, M., ZAVADSKASB, E.K., TURSKIS Z., \& ANTUCHEVICIENEB, J. (2017). "Stochastic EDAS Method for Multi-Criteria Decision-Making with Normally Distributed Data". Journal of Intelligent\&Fuzzy Systems, 33: 1627-1638.

KOCAMAN, A.M., MUTLU, E.M., BAYRAKTAR, D., \& ARAZ, Ö.M. (2012). 'OECD Ülkelerinin Sağlık Sistemlerinin Etkinlik Analizi', Endüstri Mühendisliği Dergisi, 23(4): 14-31. 
KUTUT, V., ZAVADSKAS, E.K., \& LAZAUSKAS, M. (2014). "Assessment of Priority Alternatives for Preservation of Historic Buildings Using Model based on ARAS and AHP Methods". Archives of Civil and Mechanical Engineering, 14: 287-294.

MIRMIRANI, S., \& LIPPMANN, M. 2003. "Health Care System Efficiency Analysis of G12 Countries". International Business \& Economics Research Journal, 3(5):35-42.

MUT, S., \& AKYÜREK Ç.E. (2017). “OECD Ülkelerinin Sağlık Göstergelerine Göre Kümeleme Analizi İle Sınıflandırılması". International Journal of Academic Value Studies, 3(12): 411-422.

OECD (2018). https://data.oecd.org/searchresults, 31.10.2018.

ÖZBEK, A. (2017). Çok Kriterli Karar Verme Yöntemleri ve Excel ile Problem Çözümü, Seçkin Yayıncılık, Ankara.

ÖZBEK, A. (2019). "Türkiye'deki İllerin EDAS ve WASPAS Yöntemleri ile Yaşanabilirlik Kriterlerine Göre Siralanması". Kırıkkale Üniversitesi Sosyal Bilimler Dergisi, 9(1): 177-200.

ÖZBEK, A., \& ENGÜR, M. (2018). "EDAS Yöntemi ile Lojistik Firma Web Sitelerinin Değerlendirilmesi".Selçuk Üniversitesi Sosyal Bilimler Meslek Yüksekokulu Dergisi, 21(2): 417-429.

ÖZDEMİR, A.İ. (2009). "Hizmet Sektörü Etkinliğinin Makro Düzeyde İncelenmesi: Karadeniz Ekonomik İşbirliği Teşkilatı Üyesi Ülkelerin Sağlık Sektörü Üzerine Bir Analiz'’.Erciyes Üniversitesi İktisadi ve İdari Bilimler Fakültesi Dergisi, 33: 189-205.

PAUL, D., AGARWAL, P.K., \& CHAKRABORTY, S. (2016). " Performance Appraisal of Indian State Police Forces Using ARAS Method".Management Science Letters, 6:361-372.

RETZLAFF, R. D., CHANG, C. F., \& RUBIN, R. M. (2004). "Technical Efficiency in the Use of Health Care Resources: A Comparison of OECD Countries'. Health Policy, 69(1): 55-72.

REZA, S., \& MAJID, A. (2013). "Ranking Financial Institutions Based on of Trust in Online Banking Using ARAS and ANP Method". International Research Journal of Applied and Basic Sciences,6(4): 415-423.

RUZGYS, A., VOLVAČIOVAS, R., IGNATAVIČIUS, Č., \& TURSKIS, Z. (2014). "Integrated Evaluation of External Wall Insulation in Residential Buildings Using SWARA-TODIM MCDM Method". Journal of Civil Engineering and Management, 20(1): 103-110.

SAYILI, U. (2017). "Türkiye ve OECD Ülkelerinin Sağlık Göstergeleri ve Sağlık Harcamalarının Karşılaştırılması". Online Türk Sağlık Bilimleri Dergisi, 2(3): 1-12.

SAYILI, U., AKSU SAYMAN, Ö., VEHIDİ, S., KÖKSAL S., \& ERGINÖZ E. (2017). "Türkiye ve OECD Ülkelerinin Sağlık Göstergeleri ve Sağlık Harcamalarının Karşılaştırılması'’. Online Türk Sağlık Bilimleri Dergisi, 2(3). 1-12. 
SHARIATI, S., CHAMZINI, A.Y., SALSANI, A., \& TAMOSAITIENE, J. (2014),."Proposing a New Model for Waste Dump Site Selection: Case Study of Ayerma Phosphate Mine". 25(4): 410-419.

SLIOGERIENE, J., TURSKIS, Z., \& STREIMIKIENE, D. (2013). "Analysis and Choice of Energy Technologies: The Multiple Criteria Assessment on the Case Study of Lithuania". Energy Procedia, 32:11-20.

SPINKS, J., \& HOLLINGSWORTH, B. (2005). "Cross-Country Comparisons of Technical Efficiency of Health Production: A Demonstration of Pitfalls". Journal of Applied Economics, 41(4): 417-427.

STANUJKIC, D., \& JOVANOVIC, R. (2012). "Measuring a Quality of Faculty Website Using ARAS Method". Contemporary Issues in Business, Management and Education, 545-554.

STANUJKIC, D., KARABAŠEVIĆ, D., \& ZAVADSKAS, K.E. (2015). "A Framework for the Selection of a Packaging Design Based on the SWARA Method". Inzinerine Ekonomika-Engineering Economics, 26(2): 181-187.

ŞENER, M., \& YİĞİT, V. (2017). "Sağlık Sistemlerinin Teknik Verimliliği: OECD Ülkeleri Üzerinde Bir Araştırma". Süleyman Demirel Üniversitesi Sosyal Bilimler Enstitüsü Dergisi, 1(26): 266-290.

TANDON, A. (2005). "Measuring Efficiency of Macro Systems: An Application to Millennium Development Goal Attainment", Asian Development Bank, Phillippines.

TEKİN, B. (2015). “Temel Sağlık Göstergeleri Açısından Türkiye'deki İllerin Gruplandırılması: Bir Kümeleme Analizi Uygulaması'’. Çankırı Karatekin Üniversitesi İktisadi ve İdari Bilimler Fakültesi Dergisi, 5(2): 389-416.

TUŞ IŞIK, A., \& ADALI, A.E. (2016). "A New Integrated Decision Making Approach Based on SWARA and OCRA Methods for the Hotel Selection Problem".Int. J. Advanced Operations Management, 8(2): 140-151.

ULUTAŞ, A. (2017). "EDAS Yöntemi Kullanılarak Bir Tekstil Atölyesi için Dikiş Makinesi Seçimi".İşletme Araştırmaları Dergisi, 9(2): 169-183.

VESKOVIĆ, S., STEVIĆ, Ž., STOJIĆ, G., VASILJEVIĆ M., \& MILINKOVIĆ S. (2018). "Evaluation of the Railway Management Model by Using A New Integrated Model DELPHI-SWARA-MABAC". Decision Making: Applications in Management and Engineering, 1(2): 34-50.

World Health Organization (2018). https://www.who.int/gho/countries/en/ , 31.10.2018.

YILDIRIM, B.F. (2015). "Çok Kriterli Karar Verme Problemlerinde Aras Yöntemi". KAÜ İİF Dergisi, 6(9): 285-296.

ZAVADSKAS, E. K., \& TURSKIS, Z. (2010). "A New Additive Ratio Assessment (ARAS) Method in Multicriteria Decision Making". Technological and Economic Development of Economy, 162: 159-172. 
ZOLFANI, H.S., \& ZAVADSKAS, K.E. (2013). "Sustainable Development of Rural Areas' Building Structures Based on Local Climate".Procedia Engineering, 57: 1295-1301.

ZOLFANI, H.S., ZAVADSKAS, K.E., \& TURKIS, Z.,(2013a). "Design of Products with Both International and Local Perspectives based on Yin-Yang Balance Theory and Swara Method". Economic Research-Ekonomska Istraživanja, 26(2): 153-166.

ZOLFANI, S. H., ESFAHANI, M. H., BITARAFAN, M., ZAVADSKAS, E. K., \& AREFI, S.L. (2013b). "Developing A New Hybrid MCDM Method for Selection of the Optimal Alternative of Mechanical Longitudinal Ventilation of Tunnel Pollutants During Automobile Accidents". Transport, 28(1): 89-96.

ZOLFANI, S. H., \& BAHRAMI,M. (2014). "Investment Prioritizing In High Tech Industries based on SWARA-COPRAS Approach". Technological and Economic Development of Economy, 20(3): 534-553. 